\title{
Boehmeriasin A as new lead compound for the inhibition of Topoisomerases and SIRT2
}

Michael S. Christodoulou ${ }^{\mathrm{a}}$, Francesco Calogero ${ }^{\mathrm{a}}$, Marcus Baumann, ${ }^{\mathrm{b}}$ Aída Nelly García-Argáez, ${ }^{\mathrm{c}}$ Stefano Pieraccini, ${ }^{a}$ Maurizio Sironi, ${ }^{\text {a }}$ Federico Dapiaggi, ${ }^{a}$ Raffaella Bucci, ${ }^{\text {a }}$ Gianluigi Broggini, ${ }^{\mathrm{d}}$ Silvia Gazzola, ${ }^{\mathrm{d}}$ Sandra Liekens, ${ }^{\mathrm{e}}$ Alessandra Silvani, ${ }^{\mathrm{a}}$ Maija Lahtela-Kakkonen, ${ }^{\mathrm{f}}$ Nadine Martinet, ${ }^{\mathrm{g}}$ Alfons Nonel-Canals, ${ }^{\mathrm{h}}$ Eduardo Santamaría-Navarro, ${ }^{\mathrm{h}}$ Ian R. Baxendale, ${ }^{\mathrm{b}}$ Lisa Dalla Via ${ }^{\mathrm{c}}$ and Daniele Passarella ${ }^{\mathrm{a}, *}$

${ }^{a}$ Dipartimento di Chimica - Università degli Studi di Milano - Via Golgi 19, 20133 Milano - Italy

${ }^{h}$ Department of Chemistry - University of Durham - South Road, DH1 3LE, Durham - United Kingdom

${ }^{c}$ Dipartimento di Scienze del Farmaco - Università degli Studi di Padova - Via F. Marzolo 5, 35131 Padova - Italy

${ }^{d}$ Dipartimento di Scienza e Alta Tecnologia - Università degli Studi dell'Insubria - Via Valleggio 11, 22100 Como - Italy

${ }^{e}$ Rega Institute for Medical Research - Minderbroedersstraat 10, B-3000 Leuven - Belgium ${ }^{f}$ School of Pharmacy - University of Eastern Finland - P. O. Box 1627, 70211 Kuopio - Finland ${ }^{g}$ Institute of Chemistry - UMR CNRS 7272 - Parc Valrose, Nice 06108, Cedex 2 - France

${ }^{h}$ Mind the Byte, S.L. - Parc Científic de Barcelona - C/Baldiri Reixac, 4-8, 08028 Barcelona Spain

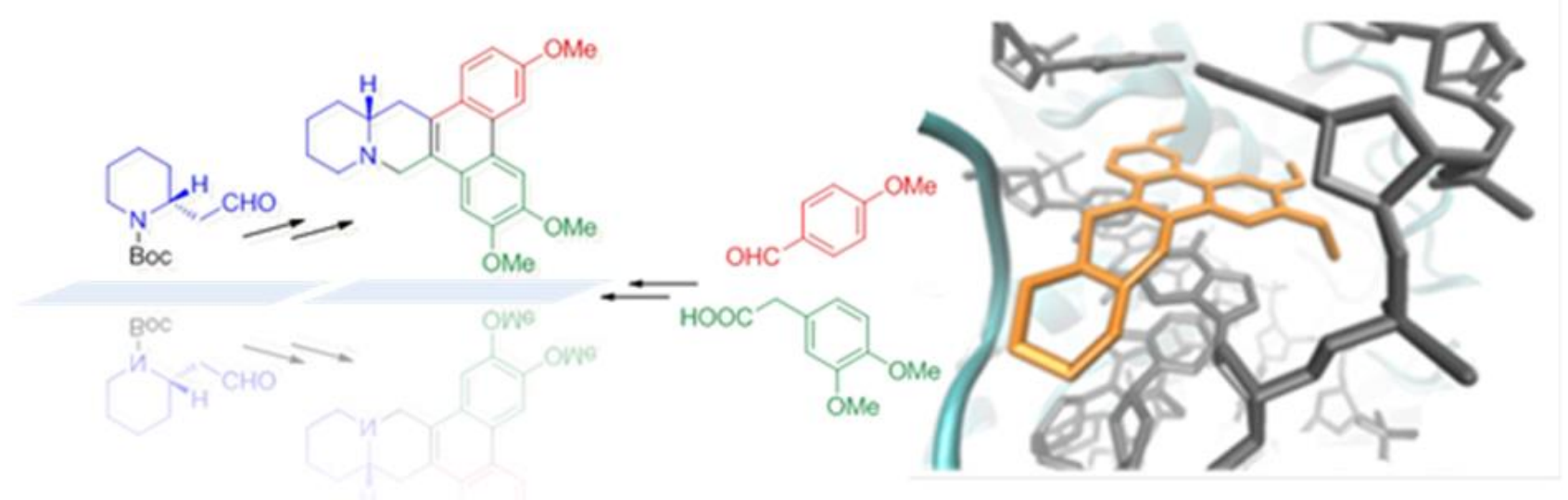

\section{ABSTRACT}

Two different approaches for the synthesis of boehmeriasin A are described. The gram scale racemic preparation is accompanied by an efficient preparation of both the pure enantiomers using the conformationally stable 2-piperidin-2-yl acetaldehyde as starting material. The anti-proliferative activity in three cancer cell lines (CEM, HeLa and L1210) and two endothelial cell lines (HMEC-1, BAEC) is promising giving activity in the nanomolar range. Topoisomerases and SIRT2 were identified as possible biological targets and the experimental data has been supported by docking studies. 


\section{INTRODUCTION}

Boehmeriasin A (Scheme 1), a phenanthroquinolizidine alkaloid, was isolated from the aqueous ethanolic extract of Boehmeria siamensis Craib (Urticaceae) by bioassay-guided fractionation. ${ }^{1}$ In vitro tests showed that boehmeriasin A possesses a strong cytotoxic activity, more potent than taxol, against 12 cell lines from 6 panels of cancer including breast, kidney, prostate, colon, lung cancer and leukemia with $\mathrm{GI}_{50}$ values between 0.2 and $100 \mathrm{ng} / \mathrm{mL}$. Furthermore, this alkaloid restrains the expression of a series of genes related to cell proliferation and cell cycle regulation. ${ }^{2}$ This results in G1 phase arrest of the cell cycle and differentiation in the breast cancer cell line MDA-MB-232. ${ }^{3}$ Consequently, we were attracted by its biological activity, the uncertainty of its biological mechanism and by the features of its structure that show boehmeriasins as possible building blocks for further structural modification. In this context we planned a convenient synthesis to both enantiomers of boehmeriasin A and the extension of the methodology to a of library of analogues. Several synthetic methodologies have been developed for the elaboration of some boehmeriasin A congeners (e.g. cryptopleurine and its hydroxy derivatives) in both racemic and optically active forms $^{4-15}$

Herein, we report two synthetic approaches to obtain the racemic mixture and the pure enantiomers of boehmeriasin A. Biological evaluation showed high anti-proliferative activity on cancer and endothelial cells with topoisomerases and SIRT2 as involved targets. Virtual screening (Hurakan tool) ${ }^{16}$ and docking studies support to the experimental results.

\section{RESULTS AND DISCUSSION}

\section{Chemistry}

The retrosynthetic plan (Scheme 1) indicates the possibility to first create the phenantrene nucleus and then conduct a further cyclization to form the quinolizidine ring (path A) or (path B). This would permit the generation of the nitrogen containing bicyclic system in a stereospecific way by an intramolecular aldol type reaction followed by an intamolecular arylation reaction.

Driven by a desire to access both enantiomers of boehmeriasin A we initiated our synthetic efforts first though a racemic preparation of the target compound. To this end we pursued the synthesis outlined in Scheme 2 which through its simplicity and robustness would allow gram scale quantities of the desired natural product to be obtained. 




The synthesis commences with a Perkin reaction between commercially available 4methoxybenzaldehyde (3) and 3,4-dimethoxyphenylacetic acid (4). This reaction can be easily performed on 100-150 mmol scale. Next a microwave assisted Fischer esterification delivered the corresponding ester $\mathbf{5}$ in quantitative yield through rapid flash heating. In the next step a ferrous chloride mediated oxidative biaryl coupling was undertaken. This transformation can be performed on multigram scale in an efficient manner, however, the generation of stoichiometric amounts of insoluble inorganic by-products requires close reaction monitoring and effective work-up strategies in order to achieve a reproducible reaction outcome (see Experimental Section). Reduction of the ester functionality of intermediate 6 using $\mathrm{LiAlH}_{4}$ and chlorodehydroxylation of the resulting benzylic alcohol 7 with concentrated $\mathrm{HCl}$ cleanly affords benzylic chloride $\mathbf{8}$. This material is subjected to nucleophilic substitution with the potassium salt of racemic pipecolic acid furnishing the desired adduct 9 without recourse to any protecting group chemistries. In order to prepare the pentacyclic scaffold of boehmeriasin A a Friedel-Crafts acylation in neat polyphosphoric acid was used. This transformation was found to reliably furnish the desired ketone $\mathbf{1 0}$ in good yield, as long as the instability of this material under basic conditions is addressed by maintaining the $\mathrm{pH}$ during 
the aqueous work-up below 8. Finally removal of the ketone functionality was accomplished in a two-step fashion firstly using $\mathrm{LiAlH}_{4}$ followed by dehydroxylation under TFA/triethylsilane conditions. In summary, this sequence allowed the preparation of racemic boehmeriasin A in a short 7 step sequence and in $22 \%$ overall yield. In addition, the feasibility of separating the racemic natural product by means of chiral HPLC was evaluated. Pleasingly, it was quickly established that for analytical purposes a short chiral HPLC column $(A D, 5 \mathrm{~cm})$ can be used in order to achieve resolution of the racemic boehmeriasin A (see insert in Scheme 2). Consequently, we feel confident that separation of the racemate on a preparative scale using a larger $\mathrm{AD}$ column can be accomplished, however, before doing so we elected to carry out an asymmetric synthesis of $(S)$ $/(R)$-boehmeriasin A.

Scheme 2. Racemic synthesis of boehmeriasin A and its resolution via chiral HPLC (path A) ${ }^{\mathrm{a}}$

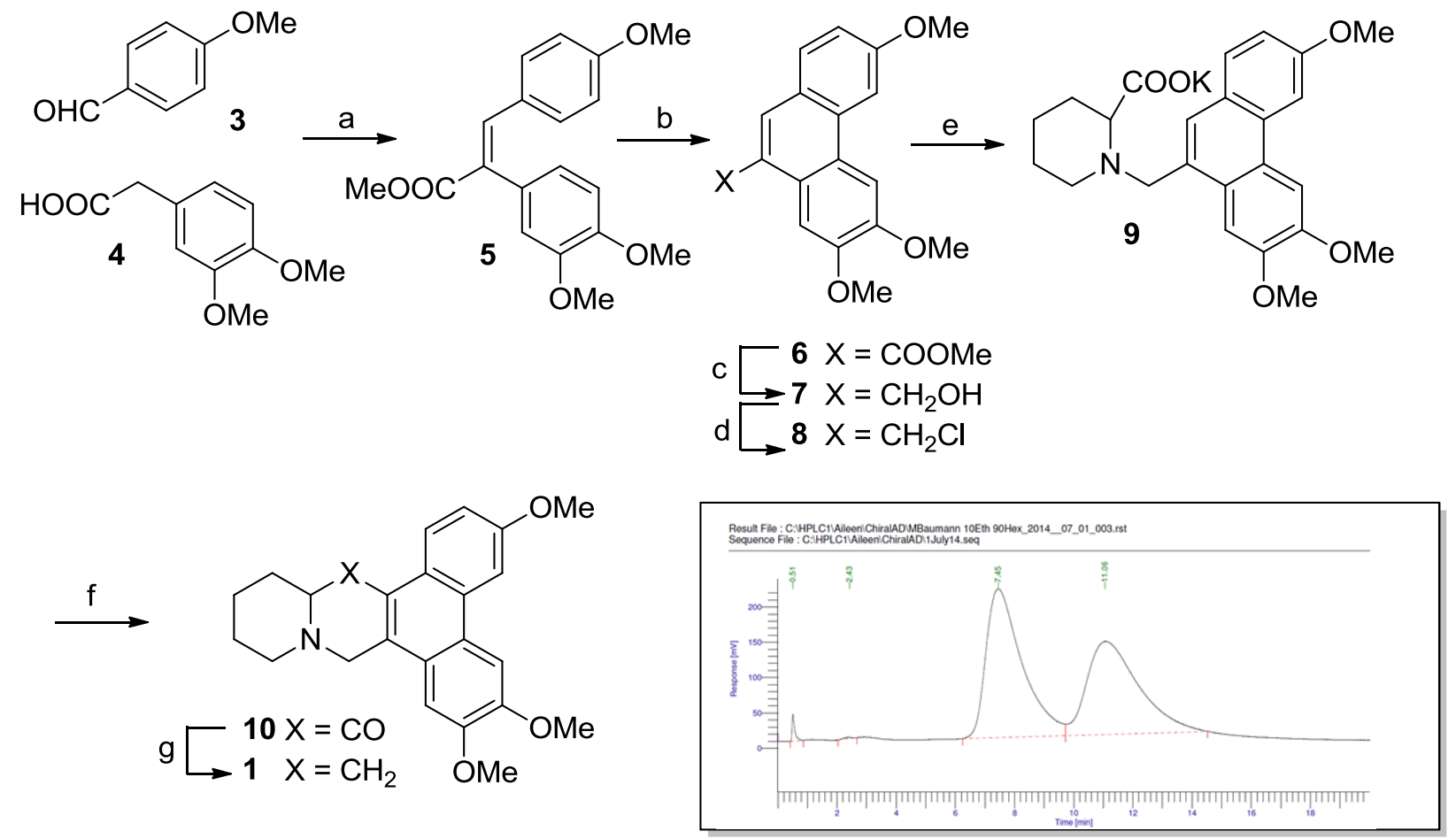

${ }^{\mathrm{a} C o n d i t i o n s: ~: ~(a) ~ i) ~} \mathrm{Et}_{3} \mathrm{~N}, \mathrm{Ac}_{2} \mathrm{O}, 120^{\circ} \mathrm{C}$, ii) $\mathrm{MeOH}, \mathrm{H}_{2} \mathrm{SO}_{4}, \mathrm{MW}, 125^{\circ} \mathrm{C}$; (b) DCM, anhydr. $\mathrm{FeCl}_{3}$, r.t.; (c) $\mathrm{LiAlH}_{4}$, THF; (d) conc. $\mathrm{HCl}$, DCM, r.t.; (e) pipecolic acid, $\mathrm{NaOH}$, iPrOH, $40{ }^{\circ} \mathrm{C}$; f) PPA, $90{ }^{\circ} \mathrm{C}$; g) i) $\mathrm{LiAlH}_{4}$, $\mathrm{THF}$, r.t. ii) $\mathrm{Et}_{3} \mathrm{SiH}, \mathrm{TFA}, \mathrm{DCM}$, r.t..

In a second approach we developed an enantioselective synthesis using enatiopure piperidinethanol 2 as starting material which can be produced at gram scale ${ }^{17}$ and used for target- ${ }^{17-21}$ and diversityoriented $^{22}$ synthesis. The aldehyde 11, obtained from oxidation of the corresponding alcohol 2, was converted to the secondary alcohol 12 by Grignard addition \{4-methoxyphenyl)magnesium bromide) (Scheme 3) in high yield (90-92\%). DMP (Dess-Martin periodinane) oxidation of alcohol 12, followed by deprotection of the Boc group $(13 \rightarrow 14)$ and $N$-acylation of the amine 14 with the 
easily prepared 2-bromo-4,5-dimethoxyphenylacetic acid ${ }^{23}$ yielded compound $\mathbf{1 5}$ in $63 \%$ (3 steps) (Scheme 3, S-enantiomer shown). An intramolecular aldol-type condensation in the presence of $\mathrm{KOH}$ furnished the desirable intermediates $\mathbf{1 6}$ as mixture of atropoisomers (85\%, 1:1 ratio).

Scheme 3. Enantioselective synthesis of boehmeriasin A (path B) ${ }^{a}$<smiles>COc1ccc(C(=O)C[C@@H]2CCCCN2C(=O)c2ccc(OC)cc2)cc1</smiles>

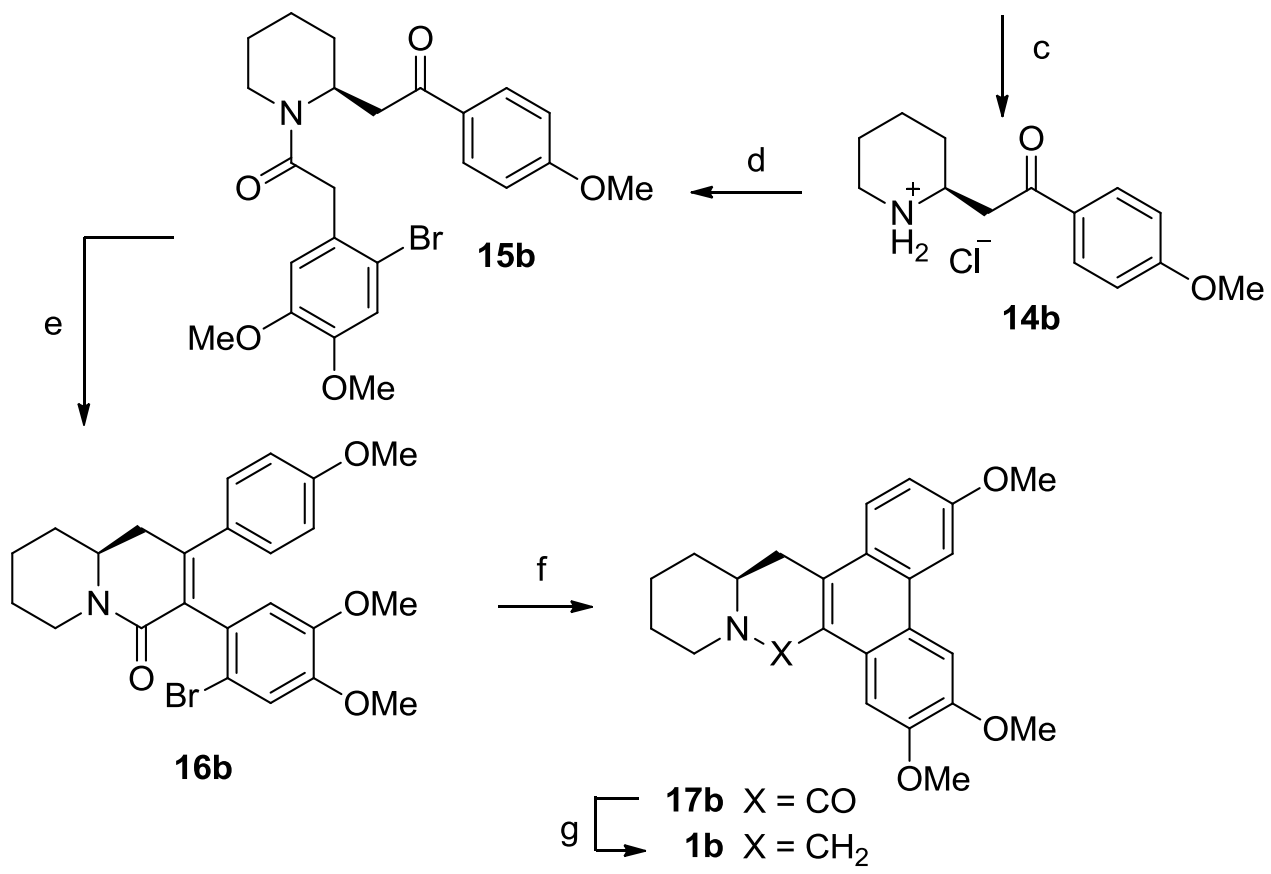

${ }^{a}$ Conditions: (a) (4-methoxyphenyl)magnesium bromide, THF, $-78{ }^{\circ} \mathrm{C}$ to r.t.; (b) DMP, r.t., 1 h; (c) TMSCl, $\mathrm{MeOH}, 0$ ${ }^{\circ} \mathrm{C}$ to r.t.; (d) 2-bromo-4,5-dimethoxyphenylacetic acid, DIPEA, HATU, THF, r.t., 1 h; (e) KOH, EtOH, reflux, 2 h; (f) $\mathrm{Pd}(\mathrm{OAc})_{2}, \mathrm{~K}_{2} \mathrm{CO}_{3}, 2^{\prime}$-(diphenylphosphino)- $N$, $N^{\prime}$-dimethyl-(1,1'-biphenyl)-2-amine, DMA, reflux, 5 h; (g) LiAlH4, THF, reflux, $2 \mathrm{~h}$.

To obtain the phenanthroindolizidine skeleton a palladium catalyzed intramolecular coupling was investigated (see Supp. Inf.). The use of $\mathrm{Pd}(\mathrm{OAc})_{2}$ in dimethylacetamide $\left(125^{\circ} \mathrm{C}\right.$ for $5 \mathrm{~h}$ ), in the presence of $\mathrm{K}_{2} \mathrm{CO}_{3}$ and 2'-(diphenylphosphino)- $N, N^{\prime}$-dimethyl-(1,1'-biphenyl)-2-amine as the ligand furnished 17 in $60 \%$ yield. A final reduction with $\mathrm{LiAlH}_{4}$, completed the synthesis of boehmeriasin A. HPLC analysis confirmed the purity of both enantiomers and was in accordance with the e.e. of the starting materials (2). 


\section{Biological Evaluation}

Anti-proliferative activity. Both enantiomers of boehmeriasin A were evaluated for their antiproliferative activity (Table 1) in three cancer cell lines [human lymphoblastic leukemia (CEM), human cervical carcinoma (HeLa) and mouse lymphocytic leukemia (L1210) cells] and two endothelial cell lines [human microvascular endothelial cells (HMEC-1) and bovine aortic endothelial cells (BAEC)]. As a reference compound, we used the vascular-targeting agent combretastatin A4P (Ca-4P), which inhibits the proliferation of the tumor cells, and endothelial cells with $\mathrm{IC}_{50}$ values around $80 \mathrm{nM}$ and $3 \mathrm{nM}$, respectively. In accordance with other results reported in the literature ${ }^{1-3,14}$ both enantiomers showed potent cytostatic activity against the different tumor cells, with $\mathrm{IC}_{50}$ values in the nanomolar range. Interestingly, $(R)-\mathbf{1}$ proved to be significantly more potent than the $(S)$-enantiomer against HeLa and L1210 cells. Both compounds also inhibited the proliferation of endothelial cells, with $\mathrm{IC}_{50}$ values of $23 \mathrm{nM}$ in BAEC and 7 and $82 \mathrm{nM}$ for the $(R)$ - and $(S)$-enantiomers in HMEC-1, respectively. Together, these data confirm the inhibitory activity of $(R)$ - and $(S)$-boehmeriasin A against both tumor and endothelial cells, the $(R)$ enantiomer being up to 11 -fold more potent than the $(S)$-enantiomer in selected cell lines.

Table 1. Anti-proliferative activity of $(R)$ - and $(S)$-boehmeriasin A in comparison with combretastatin A4P.

\begin{tabular}{|c|c|c|c|c|c|}
\hline Compound & \multicolumn{3}{|c|}{$\begin{array}{c}\text { Tumor cell lines } \\
\left(\mathrm{IC}_{50}{ }^{[\mathrm{a}]}[\mathrm{nM}]\right)\end{array}$} & \multicolumn{2}{c|}{$\begin{array}{c}\text { Endothelial cell lines } \\
\left(\mathrm{IC}_{50}{ }_{[\mathrm{a}]}[\mathrm{nM}]\right)\end{array}$} \\
\hline & HeLa & CEM & L1210 & HMEC-1 & BAEC \\
\hline$(R)-1$ & $66 \pm 56$ & $185 \pm 156$ & $19 \pm 10$ & $7.4 \pm 1.1$ & $24 \pm 13$ \\
\hline$(S)-1$ & $182 \pm 164$ & $201 \pm 127$ & $111 \pm 11$ & $82 \pm 66$ & $23 \pm 6$ \\
\hline CA-4P & $79 \pm 3$ & $95 \pm 6$ & $82 \pm 12$ & $2.9 \pm 0$ & $3.9 \pm 0.1$ \\
\hline
\end{tabular}
leukemia. HeLa: human cervical carcinoma. L1210: mouse lymphocytic leukemia cells. HMEC 1: human microvascular endothelial cells. BAEC: bovine aortic endothelial cells.

We were attracted by the possibility to identify the biological targets that could justify the antiproliferative activity on different cell lines. We wanted to avoid any structural change that could be useful for the application of interesting approaches such as surface plasmon resonance, but has the drawback to require SAR information to identify the proper alterable region of the molecule.

Virtual screening. We planned to use virtual screening with the help of Hurakan software ${ }^{16}$ that compares the input molecule with the structures present in the reference database using CoMSIA fields on a 3D grid. Hurakan uses ChemblDB as a reference database because it contains molecules, 
targets and biological activities. In this way, Hurakan predicts the biological profile of an input molecule and, in our case, it predicted 13 proteins for the $R$-enantiomer and 15 proteins for the $S$ enantiomer (see Supporting Information). We were driven by the fact that topoisomerases was identified as a possible target for $(S)$-enantiomer.

Topoisomerases inhibition. Based on our previous efforts in this field, ${ }^{25-29}$ both $(R)$ - and $(S)$ boehmeriasin A were tested for their capacity to affect the activity of opoisomerases.

Figure 1 shows the effect of $(R)$ - and $(S)$-boehmeriasin A on the relaxation of supercoiled plasmid pBR322 DNA, mediated by topoisomerase II. The enzyme relaxes supercoiled DNA (DNA) giving rise to a series of topoisomers, representing differently relaxed forms (Topo II). The test compounds were assayed at 10,25 and $50 \mu \mathrm{M}$ concentration, while $m$-AMSA, taken as reference drug, was used at $10 \mu \mathrm{M}$. Both boehmeriasins A exhibit a comparable and dose-dependent effect on enzymatic activity. Indeed, at $10 \mu \mathrm{M}$ both $(R)$ - and $(S)$-enantiomers are unable to exert a significant inhibitory activity, while the topoisomerase-mediated relaxation is completely inhibited at the higher concentration taken into account $(50 \mu \mathrm{M})$.

Figure 1. Effect of $(R)$ - and $(S)$-boehmeriasin A on relaxation of supercoiled pBR322 DNA by human recombinant topoisomerase II. $m$-AMSA was taken as reference.

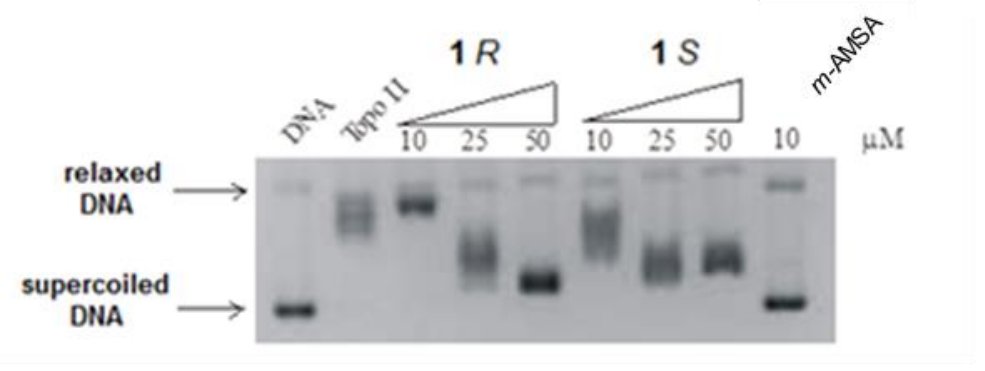

Similar experiments were performed to assay the effect on topoisomerase I relaxation activity as well, and the obtained results indicate the occurrence of a higher inhibitory effect compared to that obtained on topoisomerase II. Indeed, at $10 \mu \mathrm{M}$ concentration both $(R)$ - and $(S)$-boehmeriasin A completely inhibit the relaxation mediated by topoisomerase I (Figure 2). 
Figure 2. Effect of $(R)$ - and $(S)$-boehmeriasin A on relaxation of supercoiled pBR322 DNA by human recombinant topoisomerase I.

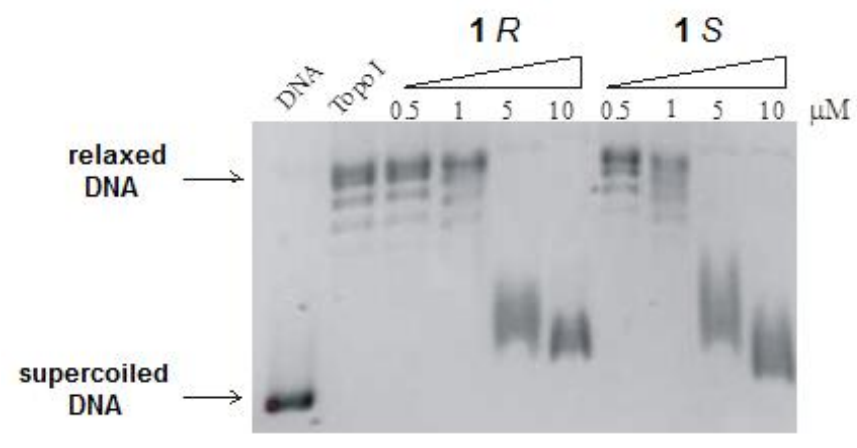

Some anti-proliferative agents, called topoisomerase poisons, interfere with topoisomerase activity by stabilizing a biological intermediate, the cleavable complex, into a lethal one. The occurrence of the cleavable complex can be demonstrated experimentally by the enzyme-dependent formation of linear (topoisomerase II) or nicked (topoisomerase I) DNA from supercoiled DNA. Figure 3 shows a cleavable complex assay performed on topoisomerase II in the presence of $100 \mu \mathrm{M}$ of (R)- and (S)-boehmeriasin A and $10 \mu \mathrm{M} m$-AMSA used as reference. The results show that both derivatives cannot stabilize the formation of the cleavage complex, although tested at a significantly higher concentration compared to that of the reference drug. Otherwise, as expected, $m$-AMSA, which is a well-known topoisomerase II poison, induces the formation of a detectable amount of linear DNA (Figure 3).

Figure 3. Effect of $(R)$ - and $(S)$-boehmeriasin A on the stabilization of covalent DNA-topoisomerase II complex. $m$ AMSA was taken as reference.

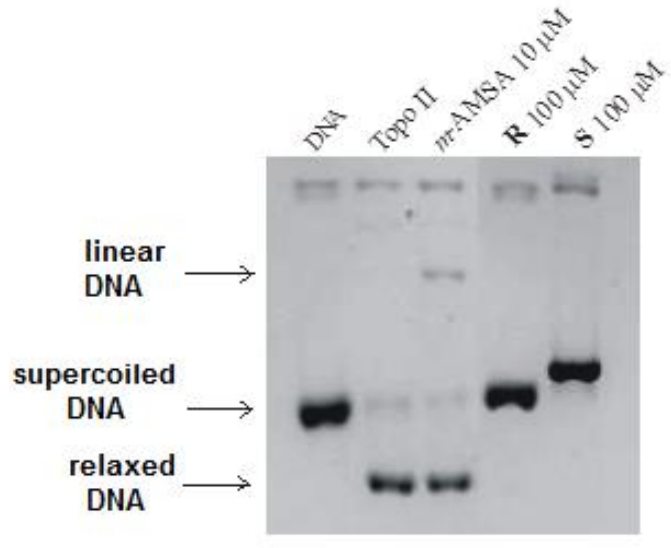

As regards topoisomerase I, the results reported in Figure 4 also show the inability of both $(R)$ - and $(S)$-boehmeriasin A to act as poison at the considered concentration $(0.5 \mu \mathrm{M})$. On the other hand, 
the topoisomerase I poison camptothecin (CPT), taken as reference, induces in the same experimental conditions the occurrence of the band corresponding to nicked DNA (Figure 4).

Figure 4. Effect of $(R)$ - and $(S)$-boehmeriasin A on the stabilization of covalent DNA-topoisomerase I complex. Camptothecin (CPT) was taken as reference.

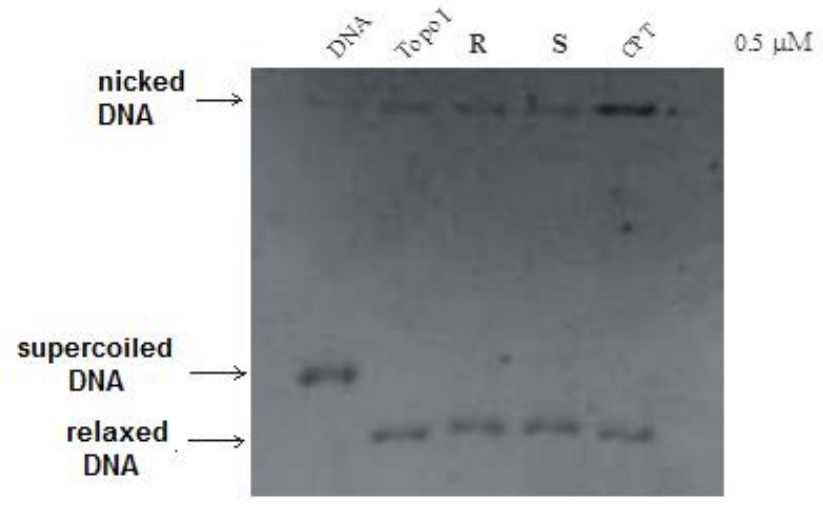

Finally, the ability of $(R)$ - and $(S)$-boehmeriasin A to interfere with topoisomerase-mediated relaxation activity, along with the lack of poisoning effect, suggest that the effect on the enzymatic activity could come from the capacity of the compounds to form a molecular complex with DNA.

Sirtuins inhibition. We were driven to study boehmeriasin A against sirtuins because it has some structural similarity with known sirtuin inhibitors. ${ }^{30}$ Both enantiomers were screened in vitro against SIRT1 and SIRT2 at $200 \mu \mathrm{M}$ concentration (Table 2). For SIRT1 $(R)$ - and $(S)$-boehmeriasin A showed no inhibition. Interestingly, for SIRT2 $(R)$-boehmeriasin A gave $\sim 65 \%$ inhibition, whereas (S)-boehmeriasin A gave only $41 \%$ inhibition.

Table 2. Evaluation of $(R)$ - and $(S)$-boehmeriasin A against SIRT1 and SIRT2.

\begin{tabular}{|c|c|c|}
\hline Compound & SIRT1 & SIRT2 \\
\hline$(R)-\mathbf{1}$ & $12 \pm 1.4$ & $65 \pm 1.6$ \\
\hline$(S)-\mathbf{1}$ & $10 \pm 4.2$ & $41 \pm 0.56$ \\
\hline Control & $100 \pm 0.06$ & $100 \pm 0.26$ \\
\hline
\end{tabular}

Docking Studies. To gain better insight of the interactions between boehmeriasin A with topoisomerases and sirtuins, molecular dockings studies were carried out.

Topoisomerases - Boehmeriasin A has a polycyclic structure and contains a phenantrene moiety that suggest it could act as a DNA intercalant, thus inhibiting topoisomerase action. The structure of topoisomerase I/DNA complex has been crystallised in complex with camptothecin, while 
topoisomerase II-beta/DNA has been obtained in complex with amsacrine, both well-known topoisomerase inhibitors, which are bound into the enzyme mediated DNA cleavage site intercalating between DNA base pairs. The pockets formed by camptothecin and amsacrine upon binding to DNA in complex with topoisomerase I and II, respectively have been chosen as the putative binding sites of boehmeriasin A (see the Experimental Section). Both $R$ and $S$ enantiomers have been docked. Docking simulations on topoisomerase I showed that both boehmerasin enantiomers display good binding affinity to the target. Cluster analysis showed two major clusters, comprising $50 \%$ and $36 \%$ of the docked structures of the $S$ enantiomer (Figure 5), and two minor clusters. All these clusters are almost isoenergetic, with binding energy around $-14 \mathrm{kcal} / \mathrm{mol}$. The $R$ enantiomer, on the other hand, displayed one dominant cluster, comprising $98 \%$ of the docking decoys (Figure 6). Cluster analysis of the docking results on the topoisomerase II showed only one cluster for the $S$ enantiomer, with the phenantrene moiety stacked between the DNA bases (Figure 7). The binding energy of the best fit structure is $-16.52 \mathrm{kcal} / \mathrm{mol}$. The $R$ enantiomer showed two distinct clusters: the principal one populated by $66 \%$ of the docked structures and the secondary one containing 34\% of the docked structures (Figure 8). The binding energy of the best fit structures of the two aforementioned clusters are -15.63 and $-15.37 \mathrm{kcal} / \mathrm{mol}$, respectively. Generally, the energy difference between clusters of docked structures of the same enantiomer, as well as the binding energy difference between $S$ and $R$ enantiomers bound to the same target is not significant in both targets. This fact can be ascribed to the identical nature of the stacking interactions observed in all the docked structures. It's worth noting that the error associated to the Autodock empirical score function is estimated around $\pm 2 \mathrm{kcal} / \mathrm{mol}$, making smaller differences in energy hardly significant and interpretable. ${ }^{31}$ A slight preference toward topoisomerase II can, on the other hand, be inferred on the basis of the docking results. It's worth noting that in all the docked conformations both $S$ and $R$ enantiomers of boehmeriasin A do not display any significant contact with either one of the topoisomerase isoforms that have been tested, but seem to mainly interact with the DNA strand through stacking interactions. 
Figure 5. Docked structure of (S)-boehmeriasin A. The best fit structure of the principal cluster is depicted in orange, while the best fit structure of secondary cluster is green. Boehmerasin is intercalated between DNA bases of the nucleic acid double helix complexed with topoisomerase I.

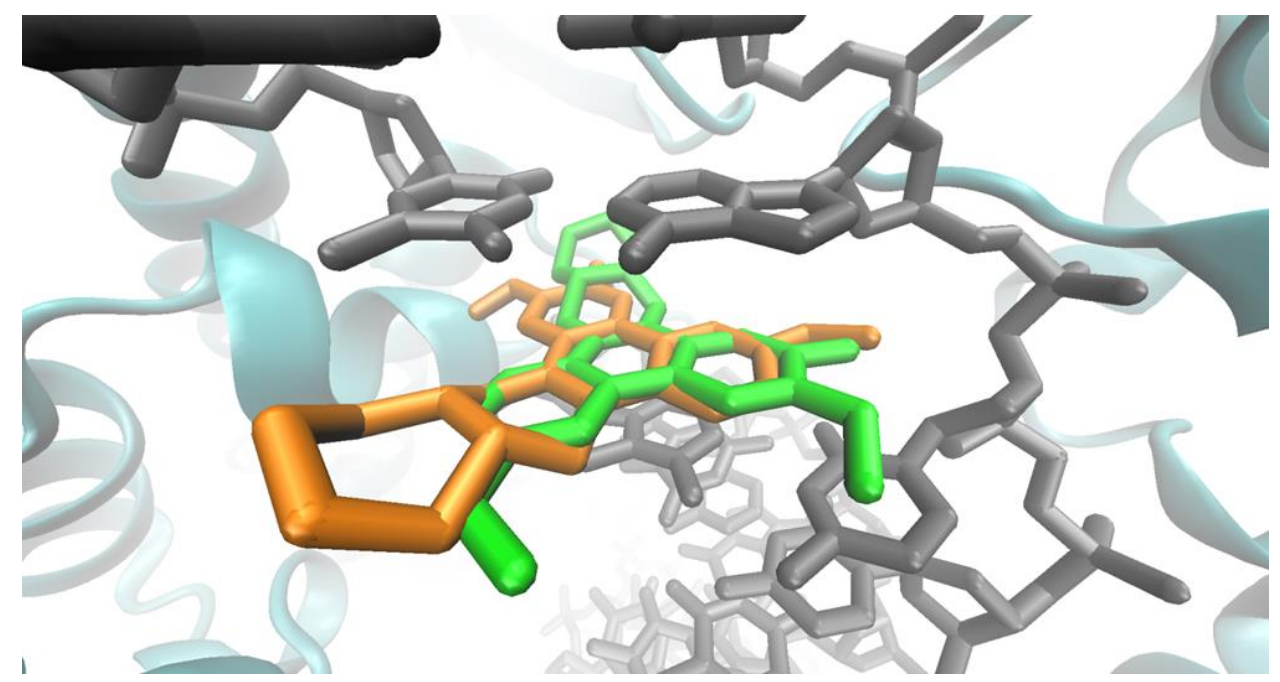

Figure 6. Docked structure of $(R)$ boehmeriasin A (blue molecule).

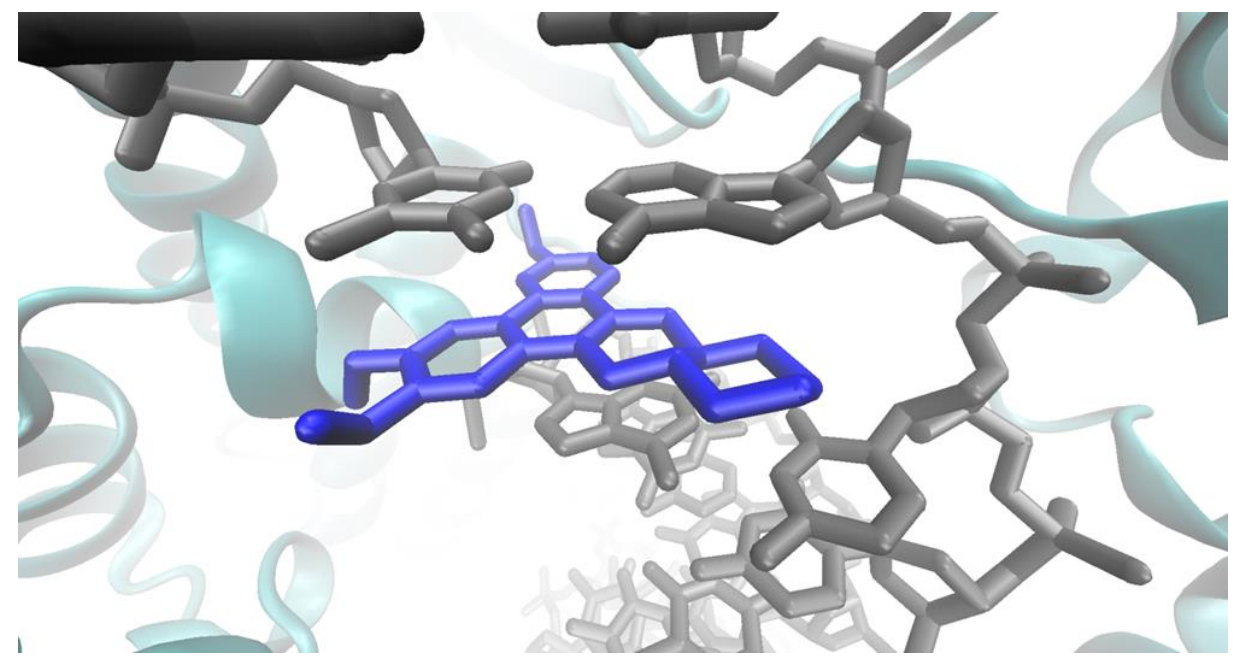

Figure 7. Docked structure of $(S)$-boehmeriasin A (orange molecule). The phenantrene moiety is intercalated between base pairs of the DNA in complex with topoisomerase II.

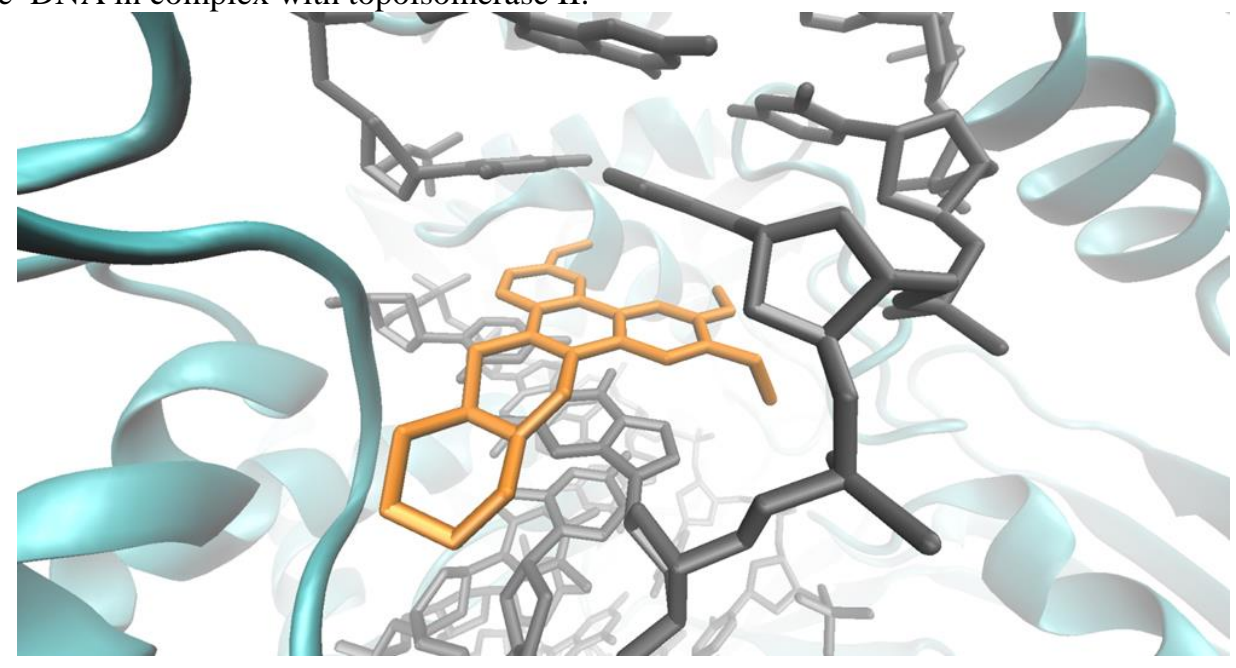


Figure 8. Docked structure of $(R)$-boehmeriasin A. The best fit structure of the principal cluster is depicted in red, while the best fit structure of secondary cluster is in blue. A very similar binding energy corresponds to these structurally different poses (see text).

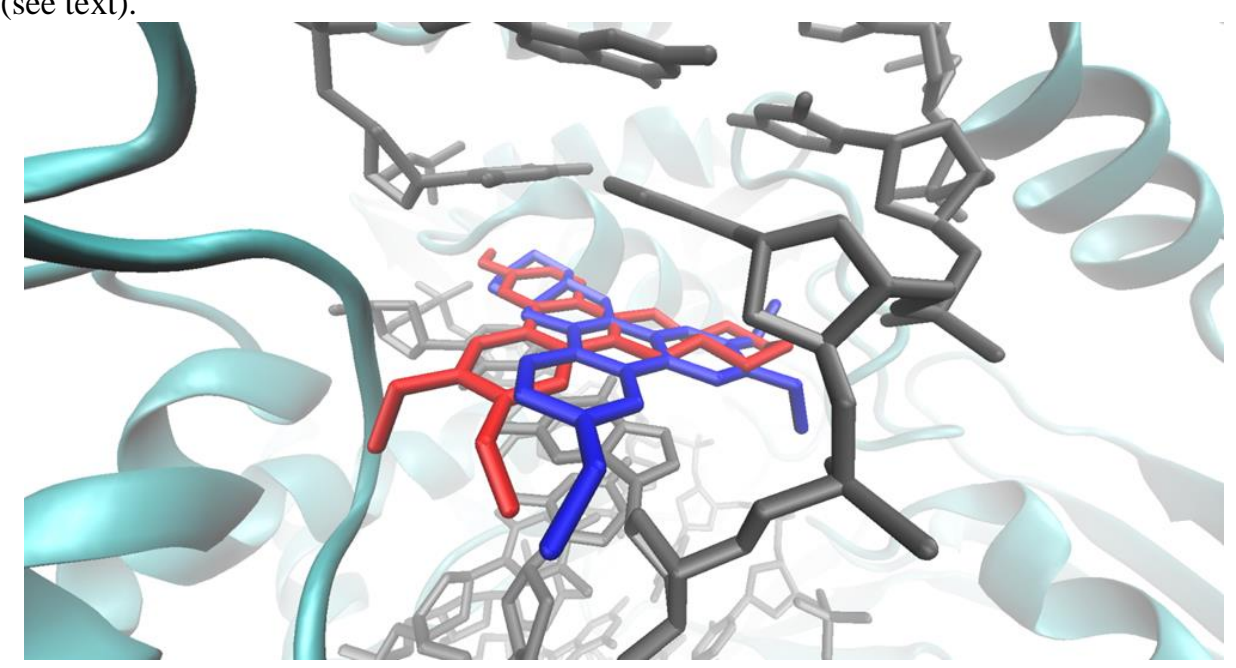

Sirtuins - In SIRT1, both enantiomers of boehmeriasin A were docked into the place of the nicotinamide-moiety (so called C-pocket in sirtuins) showing $\pi$-interactions with His 363 or Phe273 but they were not able to have proper orientation in the binding pocket (Figure 9). As for SIRT2, $(R)$-boehmeriasin A also docked into C-pocket having an interaction of the phenyl-ring with Ile169 and showed good complementary with the binding site. Whereas $(S)$-boehmeriasin A had no interactions with SIRT2, but showed also complementary binding (Figures 10 and 11). Based on the modeling there was no clear difference in the putative binding modes of the enantiomers.

Figure 9. $(R)$-Boehmeriasin A (green) in the putative binding site of SIRT2. NAD+ (black) and Ex-527(purple) is also presented based on their position in SIRT1.

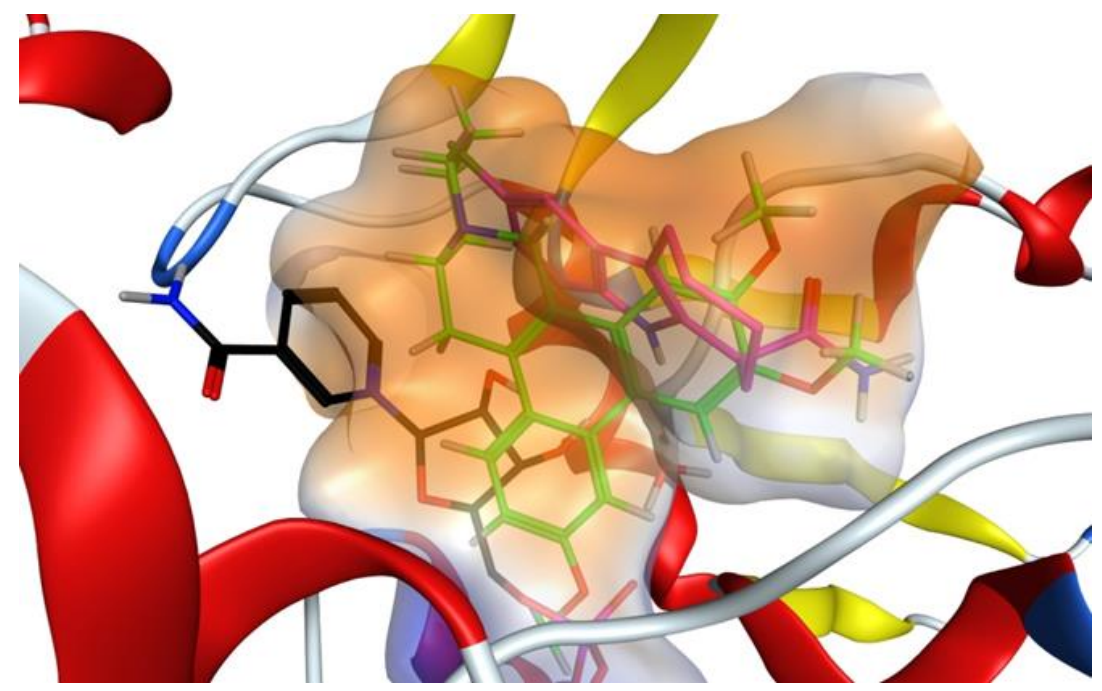


Figure 10. $(R)$-boehmeriasin A interacts with Ile169 in SIRT2. Boehmeriasin A doesn't orientate properly in the putative binding site of SIRT1.

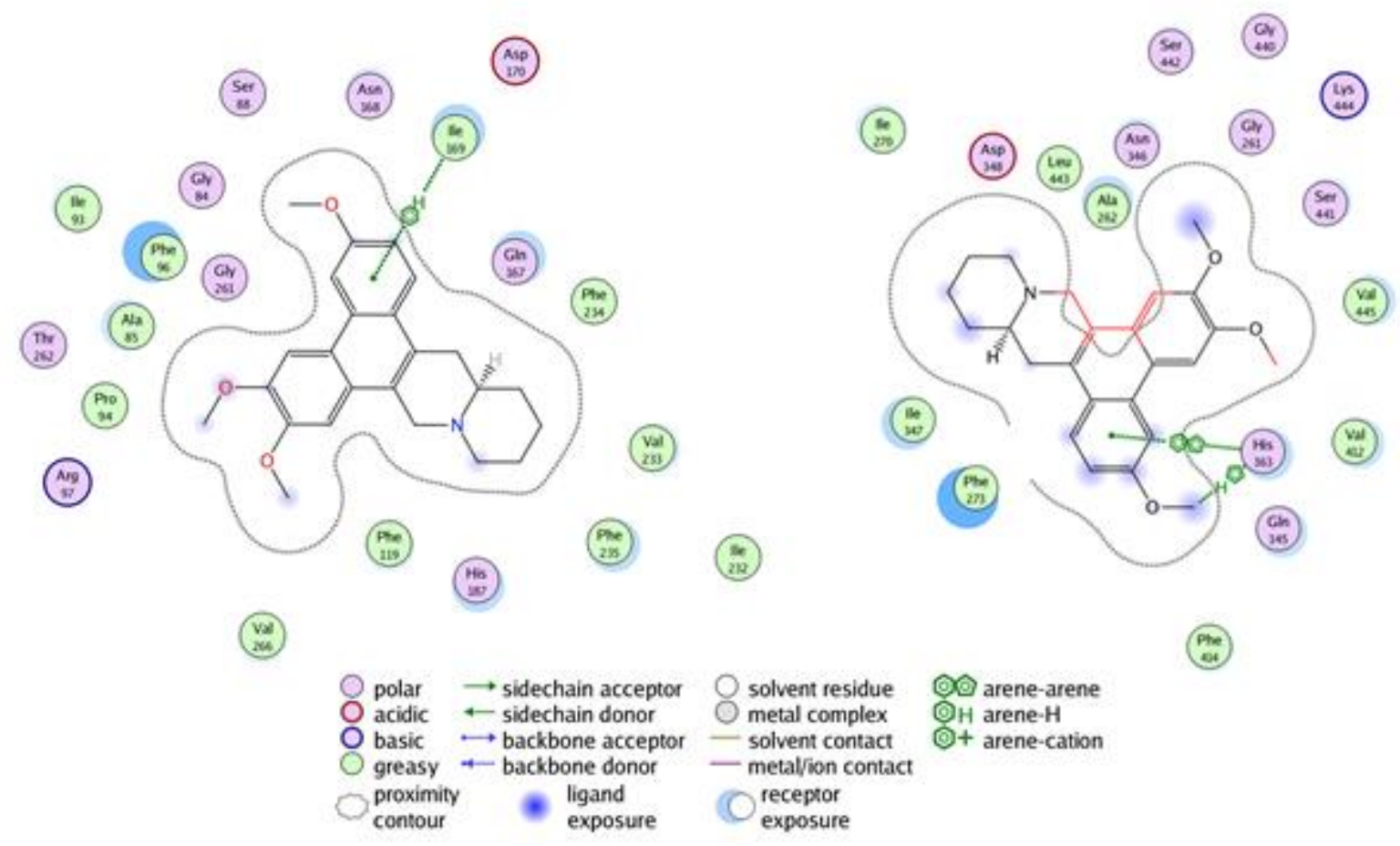

\section{CONCLUSION}

We described two different approaches for the synthesis of boehmeriasin A which in spite of being strategically based on previous reported preparations present some novelties that result in efficacy, simplicity even for large-scale production. The high anti-proliferative activity in three endothelial and two cancer cell lines was described. The biological evaluation accompanied by virtual screening and docking studies permitted to identify the interaction with DNA and SIRT2 as biological mechanisms that justify their activity. These results offer new suggestions for the design and practical synthesis of new topoisomerase and SIRT-2 inhibitors based on boehemeriasin A scaffold.

\section{EXPERIMENTAL SECTION}

\section{General procedures.}

All reactions were carried out in oven-dried glassware and dry solvents under nitrogen atmosphere. Unless otherwise stated, all solvents were purchased from Fisher Scientific and Sigma Aldrich and used without further purification. Substrates and reagents were purchased from Alfa 
Aesar or Sigma Aldrich and used as received. Thin layer chromatography (TLC) was performed on Merck precoated $60 \mathrm{~F}_{254}$ plates. Reactions were monitored by TLC on silica gel, with detection by UV light $(254 \mathrm{~nm})$ or by a solution of $\mathrm{KMnO}_{4}$ with heating. Flash chromatography was performed using silica gel (240-400 mesh, Merck). All tested compounds possessed a purity of > 98\% confirmed via elemental analyses $(\mathrm{CHN})$ in Perkin Elmer 2400 instrument. Optical rotation was measured on a JAS.CO P-1030 instrument. ${ }^{1} \mathrm{H}-\mathrm{NMR}$ spectra were recorded on either Bruker DRX400 or Bruker Avance-400 or Varian VNMRS-700 instruments and are reported relative to residual $\mathrm{CHCl}_{3}(\delta 7.26 \mathrm{ppm})$ or DMSO $(\delta 2.50 \mathrm{ppm}) .{ }^{13} \mathrm{C}-\mathrm{NMR}$ spectra were recorded on the same instruments $(100 \mathrm{MHz}$ or $175 \mathrm{MHz})$ and are reported relative to $\mathrm{CDCl}_{3}(\delta 77.16 \mathrm{ppm})$ or $\mathrm{d}_{6}$-DMSO ( $\delta 39.52 \mathrm{ppm})$. Chemical shifts $(\delta)$ for proton and carbon resonances are quoted in parts per million (ppm) relative to tetramethylsilane (TMS), which was used as an internal standard. COSY, HSQC, HMBC and NOESY experiments were used in the structural assignment. Low and high resolution mass spectrometry was performed using the indicated techniques on either Waters LCT Premier XE or Waters TQD instruments equipped with Acquity UPLC and a lock-mass electrospray ion source. EI mass spectra were recorded at an ionizing voltage of $6 \mathrm{Kev}$ on a VG 70-70 EQ. Melting ranges were recorded on an Optimelt automated melting point system and are uncorrected operating at a heating rate of $1^{\circ} \mathrm{C} / \mathrm{min}$.

(E)-Methyl 2-(3,4-dimethoxyphenyl)-3-(4-methoxyphenyl)acrylate (5). 4-Methoxybenzaldehyde (3) (13.6 g, $100 \mathrm{mmol}$ ) and 3,4-dimethoxyphenylacetic acid (4) (19.6 g, $100 \mathrm{mmol})$ were dissolved in a mixture of triethylamine $(10 \mathrm{~mL})$ and acetic anhydride $(20 \mathrm{~mL})$ and heated at $120{ }^{\circ} \mathrm{C}$ for $30 \mathrm{~h}$. After the reaction mixture was cooled to room temperature ethyl acetate $(150 \mathrm{~mL})$ was added leading to precipitation of a yellow solid. After filtration and drying this material was charged into $20 \mathrm{~mL}$ microwave vessels $(\sim 4 \mathrm{~g}$ each), filled with $7 \mathrm{~mL}$ methanol and $0.1 \mathrm{~mL}$ conc. sulfuric acid and sealed with the appropriate cap. Each of these samples was heated in a Biotage Microwave Synthesizer for $90 \mathrm{~min}$ at $125^{\circ} \mathrm{C}$. Upon cooling to $\mathrm{rt}$ the desired ester product precipitated as pale 
yellow solid and was isolated by filtration. Yield (over 2 steps) 70-75\% (23-25g); mp 106.7-107.9 ${ }^{\circ} \mathrm{C}(\mathrm{MeOH}) .{ }^{1} \mathrm{H} \mathrm{NMR}\left(\mathrm{CDCl}_{3}, 400 \mathrm{MHz}\right) \delta: 7.77(1 \mathrm{H}, \mathrm{s}), 7.02(2 \mathrm{H}, \mathrm{d}, J=8.8 \mathrm{~Hz}), 6.89(1 \mathrm{H}, \mathrm{d}, J=$ $8.0 \mathrm{~Hz}), 6.78(1 \mathrm{H}, \mathrm{dd}, J=8.0 \mathrm{~Hz} J=1.6 \mathrm{~Hz}), 6.73(1 \mathrm{H}, \mathrm{d}, J=1.6 \mathrm{~Hz}), 6.69(2 \mathrm{H}, \mathrm{d}, J=8.8 \mathrm{~Hz})$, $3.92(3 \mathrm{H}, \mathrm{s}), 3.80(3 \mathrm{H}, \mathrm{s}), 3.78(3 \mathrm{H}, \mathrm{s}), 3.75(3 \mathrm{H}, \mathrm{s}) .{ }^{13} \mathrm{C} \mathrm{NMR}\left(\mathrm{CDCl}_{3}, 100 \mathrm{MHz}\right) \delta: 168.7,160.3$, $149.1,148.6,140.2,132.4,129.6,128.6,127.3,122.1,113.7,112.8,111.4,55.88,55.81,55.22$, 52.29. ESI-MS: $351.8[\mathrm{M}+\mathrm{Na}]^{+}$. HR-MS: calculated for $\mathrm{C}_{19} \mathrm{H}_{21} \mathrm{O}_{5} 329.1389$, found 329.1393.

Methyl 3,6,7-trimethoxyphenanthrene-9-carboxylate (6). (E)-methyl 2-(3,4-dimethoxyphenyl)3-(4"'-methoxyphenyl)acrylate (5) (4 g, $12.2 \mathrm{mmol})$ was dissolved in DCM (40 mL) at rt. To this solution anhydrous $\mathrm{FeCl}_{3}(5 \mathrm{~g}, 31 \mathrm{mmol})$ was added portionwise. The resulting reaction mixture was stirred at ambient temperature for $3 \mathrm{~h}$ after which more anhydrous $\mathrm{FeCl}_{3}(1 \mathrm{~g}, 6 \mathrm{mmol})$ was added. After a total reaction time of $5 \mathrm{~h}$ complete consumption of substrate was achieved (monitored by ${ }^{1} \mathrm{H}$ NMR). Methanol ( $\left.30 \mathrm{~mL}\right)$ was added to this crude mixture resulting in a homogeneous red-brownish solution, which was subsequently extracted with DCM/water giving the desired phenanthrene product as dark brown foam after evaporation of the solvents. Filtration of the dried organic layer over a plug of silica gel (10 g) prior to solvent removal yields the desired product as light brown foam. At this scale the isolated yield commonly varied from $60-75 \%$ (>90\% purity). ${ }^{1} \mathrm{H}$ NMR $\left(\mathrm{CDCl}_{3}, 400 \mathrm{MHz}\right) \delta: 8.64(1 \mathrm{H}, \mathrm{s}), 8.43(1 \mathrm{H}, \mathrm{s}), 7.85(1 \mathrm{H}, \mathrm{s}), 7.84(1 \mathrm{H}, \mathrm{d}, J=8.8$ Hz), $7.79(1 \mathrm{H}, \mathrm{d}, J=2.4 \mathrm{~Hz}), 7.20(1 \mathrm{H}, \mathrm{dd}, J=8.8 \mathrm{~Hz} J=2.4 \mathrm{~Hz}), 4.10(3 \mathrm{H}, \mathrm{s}), 4.08(3 \mathrm{H}, \mathrm{s}), 4.02$ $(3 \mathrm{H}, \mathrm{s}), 4.01(3 \mathrm{H}, \mathrm{s}) .{ }^{13} \mathrm{C} \mathrm{NMR}\left(\mathrm{CDCl}_{3}, 100 \mathrm{MHz}\right) \delta: 168.2,160.2,149.9,148.9,133.4,131.8$, 131.3, 125.2, 125.0, 124.2, 121.6, 116.0, 106.9, 103.7, 103.2, 55.90, 55.87, 55.53, 52.03. ESI-MS: $327.0[\mathrm{M}+\mathrm{H}]^{+}$. HR-MS: calculated for $\mathrm{C}_{19} \mathrm{H}_{19} \mathrm{O}_{5} 327.1232$, found 327.1240.

(3,6,7)-Trimethoxyphenanthren-9-yl)-methanol (7). Methyl 3,6,7-trimethoxyphenanthrene-9carboxylate (6) $(3.26 \mathrm{~g}, 10.0 \mathrm{mmol})$ was dissolved in THF $(20 \mathrm{~mL})$ and cooled to $0{ }^{\circ} \mathrm{C}$. To this vigorously stirred solution, $\mathrm{LiAlH}_{4}(880 \mathrm{mg}, 25 \mathrm{mmol})$ was added in small portions over a period of 
$10 \mathrm{~min}$. After $30 \mathrm{~min}$ the ice bath was removed allowing the reaction mixture to warm to rt where it was maintained for $2 \mathrm{~h}$. Upon quenching of the reaction mixture with sat. $\mathrm{NH}_{4} \mathrm{Cl}(2 \mathrm{~mL})$ a greyish slurry was obtained which was filtered over a plug of silica (eluent DCM). The desired reduction product was obtained after removal of the volatiles as a pale yellow amorphous solid. Yield 95\% (2.82 g). ${ }^{1} \mathrm{H}$ NMR $\left(\mathrm{CDCl}_{3}, 700 \mathrm{MHz}\right) \delta: 7.79(1 \mathrm{H}, \mathrm{s}), 7.73(1 \mathrm{H}, \mathrm{d}, J=2.1 \mathrm{~Hz}), 7.69(1 \mathrm{H}, \mathrm{d}, J=9.1$ Hz), $7.51(1 \mathrm{H}, \mathrm{s}), 7.45(1 \mathrm{H}, \mathrm{s}), 7.15(1 \mathrm{H}, \mathrm{dd}, J=9.1 \mathrm{~Hz} J=1.2 \mathrm{~Hz}), 5.01(2 \mathrm{H}, \mathrm{s}), 4.06(3 \mathrm{H}, \mathrm{s}), 4.01$

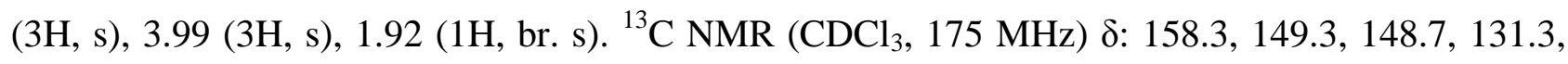
$131.1,130.1,125.7,125.5,124.8,124.4,115.4,104.8,103.9,103.7,64.59,55.91,55.86,55.47$. ESI-MS: $281.0[\mathrm{M}-\mathrm{OH}]^{+}$. HR-MS: calculated for $\mathrm{C}_{18} \mathrm{H}_{17} \mathrm{O}_{3}(\mathrm{M}-\mathrm{OH}) 281.1178$, found 281.1186.

10-(Chloromethyl)-2,3,6-trimethoxyphenanthrene (8). To a vigorously stirred solution of $(3,6,7)$ trimethoxyphenanthren-9-yl)-methanol (7) (3.0 g, $10 \mathrm{mmol}$, in DCM) was added conc. $\mathrm{HCl}$ (37 \%, $5 \mathrm{~mL}$ ) changing the color of the initial pale yellow solution to dark brown. After $2 \mathrm{~h}$ at $\mathrm{rt}$ the reaction is directly extracted $\left(\mathrm{DCM} / \mathrm{H}_{2} \mathrm{O}\right)$ giving the title compound $\mathbf{8}$ as brown solid after removal of the solvent. Yield 98\% (3.1 g). ${ }^{1} \mathrm{H} \mathrm{NMR}\left(\mathrm{CDCl}_{3}, 400 \mathrm{MHz}\right) \delta: 7.76(1 \mathrm{H}, \mathrm{s}), 7.70(1 \mathrm{H}, \mathrm{d}, J=2.4$ $\mathrm{Hz}), 7.66(1 \mathrm{H}, \mathrm{d}, J=8.4 \mathrm{~Hz}), 7.51(1 \mathrm{H}, \mathrm{s}), 7.40(1 \mathrm{H}, \mathrm{s}), 7.14(1 \mathrm{H}, \mathrm{dd}, J=8.4 \mathrm{~Hz} J=2.4 \mathrm{~Hz}), 4.92$ $(2 \mathrm{H}, \mathrm{s}), 4.05(3 \mathrm{H}, \mathrm{s}), 4.04(3 \mathrm{H}, \mathrm{s}), 3.96(3 \mathrm{H}, \mathrm{s}) .{ }^{13} \mathrm{C} \mathrm{NMR}\left(\mathrm{CDCl}_{3}, 100 \mathrm{MHz}\right) \delta: 158.8,149.4,148.9$, $131.7,130.4,127.9,126.8,125.2,125.1,125.0,115.6,104.7,103.8,55.96,55.91,55.47,46.11$. ESI-MS (ASAP): 316.1 [radical cation]. HR-MS: calculated for $\mathrm{C}_{18} \mathrm{H}_{18} \mathrm{O}_{3} \mathrm{Cl}$ 317.0944, found 317.0931.

Potassium 1-[(3,6,7-trimethoxyphenanthren-9-yl)methyl]piperidine-2-carboxylate (9). A suspension containing rac-pipecolic acid $(750 \mathrm{mg}, 5.8 \mathrm{mmol})$ and potassium hydroxide $(1.0 \mathrm{~g}, 17.9$ $\mathrm{mmol})$ in isopropanol $(6 \mathrm{~mL})$ is stirred at r.t. for $30 \mathrm{~min}$. To this mixture 10 -(chloromethyl)-2,3,6trimethoxyphenanthrene $(\mathbf{8})(1.6 \mathrm{~g}, 5 \mathrm{mmol})$ is added portionwise over $30 \mathrm{~min}$ creating a beige slurry. This mixture is stirred at $40{ }^{\circ} \mathrm{C}$ for $14 \mathrm{~h}$ before cooling to rt. Filtration and washing of this 
crude material, with a minimal amount of cold isopropanol $(3 \mathrm{~mL})$, yields the title compound 9 as beige solid which is used in the subsequent step without further purification. Yield $87 \%(1.9 \mathrm{~g}>90$ \% pure). ${ }^{1} \mathrm{H}$ NMR $\left(\mathrm{d}_{6}\right.$-DMSO, $\left.700 \mathrm{MHz}\right) \delta: 8.81(1 \mathrm{H}, \mathrm{s}), 7.94(2 \mathrm{H}$, br. s), $7.73(1 \mathrm{H}, \mathrm{d}, J=8.4 \mathrm{~Hz})$, $7.39(1 \mathrm{H}, \mathrm{s}), 7.11(1 \mathrm{H}, \mathrm{dd}, J=8.4 \mathrm{~Hz} J=2.8 \mathrm{~Hz}), 4.58(1 \mathrm{H}, \mathrm{d}, J=12.6 \mathrm{~Hz}), 3.97(3 \mathrm{H}, \mathrm{s}), 3.96(3 \mathrm{H}$, s), $3.92(3 \mathrm{H}, \mathrm{s}), 3.03(1 \mathrm{H}, \mathrm{d}, J=12.6 \mathrm{~Hz}), 2.54(1 \mathrm{H}, \mathrm{m}), 2.49(1 \mathrm{H}, \mathrm{m}), 1.68-1.73(2 \mathrm{H}, \mathrm{m}), 1.50-1.58$ $(2 \mathrm{H}, \mathrm{m}), 1.25-1.30(1 \mathrm{H}, \mathrm{m}), 1.10-1.18(2 \mathrm{H}, \mathrm{m}) .{ }^{13} \mathrm{C}$ NMR $\left(\mathrm{d}_{6}\right.$-DMSO, $\left.175 \mathrm{MHz}\right) \delta: 177.7,158.1$, 149.2, 149.0, 131.3, 131.0, 130.0, 127.8, 126.0, 125.5, 124.5, 115.9, 109.6, 104.2, 103.8, 71.8, 60.5, $56.68,56.11,55.88,51.41,30.87,25.97,24.63$.

\section{3,6,7-Trimethoxy-12,13,14,14a-tetrahydro-9H-dibenzo[f,h]pyrido[1,2-b]isoquinolin-15(11H)-}

one (10). Potassium 1-((3,6,7-trimethoxyphenanthren-9-yl)methyl)piperidine-2-carboxylate (9) (900 mg, $2.0 \mathrm{mmol})$ is added to polyphosphoric acid $(\sim 3 \mathrm{~g})$ and stirred at $90{ }^{\circ} \mathrm{C}$ for $4-5 \mathrm{~h}$. Within 30 min a thick black solution is obtained which is maintained at this temperature until full conversion of the substrate is obtained (monitored by LC-MS). The reaction mixture is then cooled to rt and carefully quenched by addition of methanol not allowing the temperature to rise above $\sim 40{ }^{\circ} \mathrm{C}$ (icebath). The resulting solution is then neutralized by careful addition of a saturated solution of potassium carbonate. Extractive work-up of this material with $\mathrm{DCM} / \mathrm{H}_{2} \mathrm{O}$ gives a crude product which can be purified further by column chromatography (15\% EtOAc/Hex) providing the title compound 10 as a pale yellow solid. Yield 70\%. ${ }^{1} \mathrm{H}$ NMR $\left(\mathrm{CDCl}_{3}, 700 \mathrm{MHz}\right) \delta: 9.26(1 \mathrm{H}, \mathrm{d}, J=$ $9.8 \mathrm{~Hz}), 7.24(1 \mathrm{H}, \mathrm{s}), 7.72(1 \mathrm{H}, \mathrm{d}, J=1.4 \mathrm{~Hz}), 7.22(1 \mathrm{H}, \mathrm{dd}, J=9.8 \mathrm{~Hz} J=1.4 \mathrm{~Hz}), 7.11(1 \mathrm{H}, \mathrm{s})$, $4.36(1 \mathrm{H}, \mathrm{d}, J=15.4 \mathrm{~Hz}), 4.07(3 \mathrm{H}, \mathrm{s}), 4.01(3 \mathrm{H}, \mathrm{s}), 3.97(3 \mathrm{H}, \mathrm{s}), 3.65(1 \mathrm{H}, \mathrm{d}, J=15.4 \mathrm{~Hz}), 3.19$ $(1 \mathrm{H}, \mathrm{d}, J=10.5 \mathrm{~Hz}), 2.77(1 \mathrm{H}, \mathrm{d}, J=10.5 \mathrm{~Hz}), 2.47(1 \mathrm{H}, \mathrm{d}, J=13.3 \mathrm{~Hz}), 2.40(1 \mathrm{H}, \mathrm{t}, J=13.3 \mathrm{~Hz})$, $1.96(1 \mathrm{H}, \mathrm{d}, J=13.3 \mathrm{~Hz}), 1.70-1.77(1 \mathrm{H}, \mathrm{m}), 1.66(1 \mathrm{H}, \mathrm{tq}, J=13.3 \mathrm{~Hz} J=2.8 \mathrm{~Hz}), 1.60(1 \mathrm{H}, \mathrm{q}, J=$ $13.3 \mathrm{~Hz}), 1.45(1 \mathrm{H}, \mathrm{tq}, J=13.3 \mathrm{~Hz} J=2.8 \mathrm{~Hz}) .{ }^{13} \mathrm{C} \mathrm{NMR}\left(\mathrm{CDCl}_{3}, 175 \mathrm{MHz}\right) \delta: 197.3,157.8$, $151.0,149.5,139.3,130.9,129.3,127.3,123.1,123.0,122.7,115.6,104.3,104.3,103.7,68.92$, 
55.99, 55.96, 55.89, 55.34, 54.85, 27.38, 24.98, 23.97. ESI-MS: $392.0[\mathrm{M}+\mathrm{H}]^{+}$. HR-MS: calculated for $\mathrm{C}_{24} \mathrm{H}_{26} \mathrm{O}_{4} \mathrm{~N}$ 392.1861, found 392.1855.

1-(4-Methoxyphenyl)-2-(1-tert-butoxycarbonylpiperidin-2-yl)ethanol (12). To a solution of aldehyde $11(0.34 \mathrm{~g}, 1.5 \mathrm{mmol})$ in THF $(13 \mathrm{~mL})$ at $-78^{\circ} \mathrm{C}$, (4-methoxyphenyl)magnesium bromide (6 mL, $3 \mathrm{mmol}$ ) was added, and the new solution was stirred for $10 \mathrm{~min}$ at $-78{ }^{\circ} \mathrm{C}$ and then overnight at rt. After the completion of the reaction, the solvent was evaporated in vacuum, sat. $\mathrm{NH}_{4} \mathrm{Cl}$ was added and the aqueous layer was extracted 3 times with EtOAc. The combined organic layers were washed with water and brine, dried with $\mathrm{Na}_{2} \mathrm{SO}_{4}$, filtered and evaporated. The residue was purified by flash column chromatography (Hex/EtOAc 7:3) to provide the two diastereomer alcohols 12 as oils. 12a $(R-\mathrm{COH})$ and 12b $(S-\mathrm{COH})$ : Yield 92-95\%; $\mathrm{R}_{f}=0.39(\mathrm{Hex} / \mathrm{EtOAc}, 7: 3)$; 12a $(R-\mathrm{COH}):[a]_{D}^{1 \mathrm{a}}=+35.9\left(c=0.90\right.$ in $\left.\mathrm{CHCl}_{3}\right)$, HR-MS: calculated for $\mathrm{C}_{19} \mathrm{H}_{30} \mathrm{NO}_{4} 336.2175$, found 336.2156; 12b $(S-\mathrm{COH}):[a]_{D}^{2 \mathbf{s}}=-36.6\left(c=0.92\right.$ in $\left.\mathrm{CHCl}_{3}\right)$, HR-MS found 336.2179. ${ }^{1} \mathrm{H}$ NMR $\left(\mathrm{CDCl}_{3}, 400 \mathrm{MHz}\right): \delta=7.32(2 \mathrm{H}, \mathrm{d}, J=8.4 \mathrm{~Hz}), 6.90(2 \mathrm{H}, \mathrm{d}, J=8.4 \mathrm{~Hz}), 4.61(1 \mathrm{H}, \mathrm{m}), 4.41$ $(1 \mathrm{H}, \mathrm{m}), 4.04(1 \mathrm{H}, \mathrm{m}), 3.82(3 \mathrm{H}, \mathrm{s}), 2.80(1 \mathrm{H}, \mathrm{t}, J=11.6 \mathrm{~Hz}), 2.20(1 \mathrm{H}, \mathrm{td}, J=14.0 \mathrm{~Hz} J=2.0 \mathrm{~Hz})$, $1.78-1.47(8 \mathrm{H}, \mathrm{m}), 1.52(9 \mathrm{H}, \mathrm{s}) .{ }^{13} \mathrm{C} \mathrm{NMR}\left(\mathrm{CDCl}_{3}, 100 \mathrm{MHz}\right): \delta=159.0,155.6,136.9,127.5$, $114.4,81.08,70.16,55.99,47.36,40.88,40.25,29.97,29.13,26.20,19.87 .12 \mathbf{a}(S-\mathrm{COH})$ and 12b $(R-\mathrm{COH})$ : oils; yields $92-95 \% ; \mathrm{R}_{f}=0.17(\mathrm{Hex} /$ EtOAc, $7: 3) ; \mathbf{1 2 a}(S-\mathrm{COH}):[a]_{D}^{1 \mathrm{a}}=+71.9(c=1.06$ in $\left.\mathrm{CHCl}_{3}\right)$, HR-MS: found $336.2160 ; \mathbf{1 2 b}(R-\mathrm{COH}):[a]_{D}^{2 \mathrm{~s}}=-73.3\left(c=0.98\right.$ in $\left.\mathrm{CHCl}_{3}\right)$, HR-MS: found 336.2158. ${ }^{1} \mathrm{H} \mathrm{NMR}\left(\mathrm{CDCl}_{3}, 400 \mathrm{MHz}\right): \delta=7.32(2 \mathrm{H}, \mathrm{d}, J=8.4 \mathrm{~Hz}), 6.89(2 \mathrm{H}, \mathrm{d}, J=8.4$ Hz), $4.71(1 \mathrm{H}, \mathrm{m}), 4.38(1 \mathrm{H}, \mathrm{m}), 3.94(1 \mathrm{H}, \mathrm{m}), 3.82(3 \mathrm{H}, \mathrm{s}), 2.82(1 \mathrm{H}, \mathrm{td}, J=13.2 \mathrm{~Hz} J=1.6 \mathrm{~Hz})$, $2.12(1 \mathrm{H}, \mathrm{dt}, J=14.4 \mathrm{~Hz} J=6.8 \mathrm{~Hz}), 1.85(1 \mathrm{H}, \mathrm{dt}, J=14.4 \mathrm{~Hz} J=5.6 \mathrm{~Hz}), 1.62-1.51(6 \mathrm{H}, \mathrm{m})$, $1.48(9 \mathrm{H}, \mathrm{s}), 1.43-1.40(1 \mathrm{H}, \mathrm{m}) .{ }^{13} \mathrm{C} \mathrm{NMR}\left(\mathrm{CDCl}_{3}, 100 \mathrm{MHz}\right): \delta=159.6,156.2,137.6,127.7$, $114.4,80.41,73.03,55.98,49.32,40.86,40.19,30.39,29.17,25.96,19.80$. 
1-(4-Methoxyphenyl)-2-(1-tert-butoxycarbonylpiperidin-2-yl)ethanone (13). To a solution of alcohol $12(0.22 \mathrm{~g}, 0.65 \mathrm{mmol})$ in DCM $(8.4 \mathrm{~mL})$, Dess-Martin periodinane $(0.34 \mathrm{~g}, 0.78 \mathrm{mmol})$ was added and the new mixture was stirred for $1 \mathrm{~h}$ at $\mathrm{rt}$. After the completion of the reaction, the solvent was evaporated in vacuum, $10 \% \mathrm{~K}_{2} \mathrm{CO}_{3}$ was added and the aqueous layer was extracted 3 times with EtOAc. The combined organic layers were washed with water and brine, dried with $\mathrm{Na}_{2} \mathrm{SO}_{4}$, filtered and evaporated. The residue was purified by flash column chromatography $\left(\right.$ Hex/EtOAc 7:3) to provide ketone 13 as oil. Yield $83 \% ; \mathrm{R}_{f}=0.38($ Hex/EtOAc, $7: 3) ; \mathbf{1 3 a}:[a]_{D}^{2 \mathbf{z}}=$ - 34.2 ( $c=0.95$ in $\mathrm{CHCl}_{3}$ ), HR-MS: calculated for $\mathrm{C}_{19} \mathrm{H}_{28} \mathrm{NO}_{4}$ 334.2018, found 334.2009; 13b: $[a]_{D}^{25}=+35.6\left(c=1.00\right.$ in $\left.\mathrm{CHCl}_{3}\right), \mathrm{HR}-\mathrm{MS}$ : found 334.2006. ${ }^{1} \mathrm{H} \mathrm{NMR}\left(\mathrm{CDCl}_{3}, 400 \mathrm{MHz}\right): \delta=$ $8.00(2 \mathrm{H}, \mathrm{d}, J=8.8 \mathrm{~Hz}), 6.96(2 \mathrm{H}, \mathrm{d}, J=8.8 \mathrm{~Hz}), 4.82(1 \mathrm{H}, \mathrm{m}), 4.05(1 \mathrm{H}, \mathrm{m}), 3.89(3 \mathrm{H}, \mathrm{s}), 3.18$ $(1 \mathrm{H}, \mathrm{dd}, J=14.0 \mathrm{~Hz} J=6.4 \mathrm{~Hz}), 3.12(1 \mathrm{H}, \mathrm{dd}, J=14.0 \mathrm{~Hz} J=6.4 \mathrm{~Hz}), 2.90(1 \mathrm{H}, \mathrm{td}, J=13.0 \mathrm{~Hz} J$ $=2.3 \mathrm{~Hz}), 1.64(5 \mathrm{H}, \mathrm{m}), 1.41(10 \mathrm{H}, \mathrm{s}) .{ }^{13} \mathrm{C} \mathrm{NMR}\left(\mathrm{CDCl}_{3}, 100 \mathrm{MHz}\right): \delta=197.0,163.6,154.8$, $130.6,130.1,113.8,79.57,55.49,48.44,39.44,38.99,28.38,28.13,25.34,18.90$.

1-(4-Methoxyphenyl)-2-(piperidin-2-yl)ethanone hydrochloride (14). To a cooled solution at 0 ${ }^{\circ} \mathrm{C}$ of ketone $13(0.31 \mathrm{~g}, 0.94 \mathrm{mmol})$ in $\mathrm{MeOH}(7.5 \mathrm{~mL}), \mathrm{TMSCl}(0.59 \mathrm{~mL}, 5.7 \mathrm{mmol})$ was added and the new solution was stirred overnight at rt. After the completion of the reaction, the solvent was evaporated in vacuum, to provide ketone 14 as oil. Yield $95 \% ; \mathbf{1 4 a}:[a]_{D}^{2 \mathbf{z}}=+17.5(c=1.14$ in $\left.\mathrm{CHCl}_{3}\right)$; 14b: $[a]_{D}^{2 \mathbf{z}}=-18.5\left(c=1.25\right.$ in $\left.\mathrm{CHCl}_{3}\right)$ for $(S)-14 .{ }^{1} \mathrm{H} \mathrm{NMR}\left(\mathrm{CDCl}_{3}, 400 \mathrm{MHz}\right): \delta=9.73$ $(1 \mathrm{H}, \mathrm{s}), 9.30(1 \mathrm{H}, \mathrm{s}), 7.92(2 \mathrm{H}, \mathrm{d}, J=8.0 \mathrm{~Hz}), 6.86(2 \mathrm{H}, \mathrm{d}, J=8.0 \mathrm{~Hz}), 3.84(3 \mathrm{H}, \mathrm{s}), 3.78-3.72$ (1H, m), $3.70-3.64(1 \mathrm{H}, \mathrm{m}), 3.55-3.47(2 \mathrm{H}, \mathrm{m}), 2.97-2.91(1 \mathrm{H}, \mathrm{m}), 2.00-1.80(5 \mathrm{H}, \mathrm{m}), 1.58-$ $1.50(1 \mathrm{H}, \mathrm{m}) .{ }^{13} \mathrm{C} \mathrm{NMR}\left(\mathrm{CDCl}_{3}, 100 \mathrm{MHz}\right): \delta=195.7,164.7,131.4,129.7,114.6,56.21,54.67$, $45.82,41.62,29.12,23.08,22.82$. 


\section{2-(2-Bromo-4,5-dimethoxyphenyl)-1-(2-(2-(4-methoxyphenyl)-2-oxoethyl)piperidin-1-}

yl)ethanone (15). To a solution of 2-bromo-4,5-dimethoxyphenylacetic acid (0.25 g, $0.90 \mathrm{mmol})$ in THF (23 mL), HATU (0.39 g, $0.99 \mathrm{mmol})$ and DIPEA $(0.31 \mathrm{~mL}, 1.8 \mathrm{mmol})$ were added and the new mixture was stirred for $30 \mathrm{~min}$ at $\mathrm{rt}$. Then, the solution was cooled at $0{ }^{\circ} \mathrm{C}$ and a solution of compound $14(0.24 \mathrm{~g}, 0.90 \mathrm{mmol})$ in THF $(12 \mathrm{~mL})$ and DIPEA $(200 \mu \mathrm{L})$ was added and the new solution was stirred for $1 \mathrm{~h}$ at $\mathrm{rt}$. After the completion of the reaction, the solvent was evaporated in vacuum, sat. $\mathrm{NH}_{4} \mathrm{Cl}$ was added and the aqueous layer was extracted 3 times with DCM. The combined organic layers were washed with water and brine, dried with $\mathrm{Na}_{2} \mathrm{SO}_{4}$, filtered and evaporated. The residue was purified by flash column chromatography (Hex/EtOAc 3:7) to provide compound 15 as oil. Yield 80\%; $\mathrm{R}_{f}=0.25$ (Hex/EtOAc, 3:7); 15a: $[a]_{D}^{2 \mathbf{z}}=-1.2(c=0.82$ in $\left.\mathrm{CHCl}_{3}\right)$, HR-MS: calculated for $\mathrm{C}_{24} \mathrm{H}_{29} \mathrm{BrNO}_{5} 490.1229$, found $490.1215 ; \mathbf{1 5 b}$ : $[a]_{D}^{2 \mathbf{2}}=+1.3(c=$ 0.86 in $\left.\mathrm{CHCl}_{3}\right)$, HR-MS: found 490.1210. ${ }^{1} \mathrm{H} \mathrm{NMR}\left(\mathrm{CDCl}_{3}, 400 \mathrm{MHz}\right.$, amide rotamers 1:1): rotamer a $\delta=8.05(2 \mathrm{H}, \mathrm{d}, J=8.8 \mathrm{~Hz}), 7.03(1 \mathrm{H}, \mathrm{s}), 6.97(2 \mathrm{H}, \mathrm{d}, J=8.8 \mathrm{~Hz}), 6.83(1 \mathrm{H}, \mathrm{s}), 5.33-$ $5.28(1 \mathrm{H}, \mathrm{m}), 4.00(1 \mathrm{H}, \mathrm{d}, J=16.0 \mathrm{~Hz}), 3.90(3 \mathrm{H}, \mathrm{s}), 3.87(3 \mathrm{H}, \mathrm{s}), 3.85(3 \mathrm{H}, \mathrm{s}), 3.78-3.72(2 \mathrm{H}$, m), $3.26(2 \mathrm{H}, \mathrm{d}, J=6.8 \mathrm{~Hz}), 3.23-3.20(1 \mathrm{H}, \mathrm{m}), 1.78-1.56(5 \mathrm{H}, \mathrm{m}), 1.46-1.30(1 \mathrm{H}, \mathrm{m})$ and rotamer b $\delta=7.93(2 \mathrm{H}, \mathrm{d}, J=8.8 \mathrm{~Hz}), 6.96(1 \mathrm{H}, \mathrm{s}), 6.95(2 \mathrm{H}, \mathrm{d}, J=8.8 \mathrm{~Hz}), 6.83(1 \mathrm{H}, \mathrm{s}), 4.78-$ $4.74(1 \mathrm{H}, \mathrm{m}), 4.67-4.64(1 \mathrm{H}, \mathrm{m}), 3.87(3 \mathrm{H}, \mathrm{s}), 3.85(3 \mathrm{H}, \mathrm{s}), 3.81(3 \mathrm{H}, \mathrm{s}), 3.78-3.72(2 \mathrm{H}, \mathrm{m}), 3.18$ $-3.09(2 \mathrm{H}, \mathrm{m}), 2.70(1 \mathrm{H}, \mathrm{td}, J=13.0 \mathrm{~Hz} J=2.4 \mathrm{~Hz}), 1.78-1.56(5 \mathrm{H}, \mathrm{m}), 1.46-1.30(1 \mathrm{H}, \mathrm{m}) .{ }^{13} \mathrm{C}$ NMR $\left(\mathrm{CDCl}_{3}, 100 \mathrm{MHz}\right)$ : rotamer a $\delta=197.5,170.4,164.5,149.2,149.0,131.5,130.5,128.1$, $116.0,115.3,114.6,114.0,56.74,56.21,47.40,42.72,41.55,39.65,29.99,26.29,20.00$ and rotamer b $\delta=196.4,170.1,164.3,149.2,149.0,131.0,130.3,127.7,116.0,115.0,114.6,113.5$, $56.74,56.14,50.36,41.13,39.25,38.32,27.96,26.16,19.35$.

\section{3-(2-Bromo-4,5-dimethoxyphenyl)-2-(4-methoxyphenyl)-1,6,7,8,9,9a-hexahydroquinolizin-4-}

one (16). A solution of compound $15(0.37 \mathrm{~g}, 0.76 \mathrm{mmol})$ in $5 \%$ ethanolic $\mathrm{KOH}(15.8 \mathrm{~mL})$ was refluxed for $2 \mathrm{~h}$. After the completion of the reaction, the solvent was evaporated in vacuum, sat. 
$\mathrm{NH}_{4} \mathrm{Cl}$ was added and the aqueous layer was extracted 3 times with DCM. The combined organic layers were washed with water and brine, dried with $\mathrm{Na}_{2} \mathrm{SO}_{4}$, filtered and evaporated. The residue was purified by flash column chromatography (Hex/EtOAc 4:6) to provide atropisomer compounds 16 as oils. Yield $85 \%$; 16a (mode 1$): \mathrm{R}_{f}=0.35(\mathrm{Hex} /$ EtOAc, $4: 6) ;[a]_{D}^{2 \mathrm{z}}=+57.6(c=0.89$ in $\mathrm{CHCl}_{3}$ ); HR-MS: calculated for $\mathrm{C}_{24} \mathrm{H}_{27} \mathrm{BrNO}_{4} 472.1123$, found 472.1110. 16b (mode 1): $[a]_{D}^{2 \mathbf{z}}=-$ $58.4\left(c=0.62\right.$ in $\left.\mathrm{CHCl}_{3}\right)$; HR-MS: found 472.1109. ${ }^{1} \mathrm{H}$ NMR $\left(\mathrm{CDCl}_{3}, 400 \mathrm{MHz}\right): \delta=7.01(2 \mathrm{H}, \mathrm{d}, J$ $=8.4 \mathrm{~Hz}), 7.00(1 \mathrm{H}, \mathrm{s}), 6.70(2 \mathrm{H}, \mathrm{d}, J=8.4 \mathrm{~Hz}), 6.46(1 \mathrm{H}, \mathrm{s}), 4.56(1 \mathrm{H}, \mathrm{br} . \mathrm{d}, J=13.6 \mathrm{~Hz}), 3.86$ $(3 \mathrm{H}, \mathrm{s}), 3.76(3 \mathrm{H}, \mathrm{s}), 3.68(1 \mathrm{H}, \mathrm{m}), 3.65(3 \mathrm{H}, \mathrm{s}), 2.86-2.69(3 \mathrm{H}, \mathrm{m}), 1.95-1.84(3 \mathrm{H}, \mathrm{m}), 1.58-$ $1.44(3 \mathrm{H}, \mathrm{m}) .{ }^{13} \mathrm{C} \mathrm{NMR}\left(\mathrm{CDCl}_{3}, 100 \mathrm{MHz}\right): \delta=166.8,159.8,149.3,148.7,146.3,132.2,131.3$, $131.2,129.6,116.1,115.6,115.5,114.0,56.74,56.58,55.82,54.11,43.46,38.30,34.06,25.37$, 23.97. EI-MS 392: [M-Br]. 16a (mode 2): $\mathrm{R}_{f}=0.23(\mathrm{Hex} / \mathrm{EtOAc}, 4: 6) ;[a]_{D}^{2 z}=-39.2(c=1.09$ in $\mathrm{CHCl}_{3}$ ); HR-MS: found 472.1113. 16b (mode 2): $[a]_{D}^{2 \mathbf{2}}=+40.4\left(c=1.10\right.$ in $\left.\mathrm{CHCl}_{3}\right)$; HR-MS: found 472.1034. ${ }^{1} \mathrm{H} \mathrm{NMR}\left(\mathrm{CDCl}_{3}, 400 \mathrm{MHz}\right): \delta=7.04(2 \mathrm{H}, \mathrm{d}, J=8.8 \mathrm{~Hz}), 6.99(1 \mathrm{H}, \mathrm{s}), 6.71(2 \mathrm{H}$, d, $J=8.8 \mathrm{~Hz}), 6.50(1 \mathrm{H}, \mathrm{s}), 4.62(1 \mathrm{H}$, br. d, $J=13.6 \mathrm{~Hz}), 3.85(3 \mathrm{H}, \mathrm{s}), 3.76(3 \mathrm{H}, \mathrm{s}), 3.70(3 \mathrm{H}, \mathrm{s})$, $3.67-3.60(1 \mathrm{H}, \mathrm{m}), 3.09(1 \mathrm{H}, \mathrm{dd}, J=17.2 \mathrm{~Hz} J=6.4 \mathrm{~Hz}), 2.69-2.63(2 \mathrm{H}, \mathrm{m}), 1.97-1.92(1 \mathrm{H}$, m), $1.89-1.82(1 \mathrm{H}, \mathrm{m}), 1.76-1.73(2 \mathrm{H}, \mathrm{m}), 1.70-1.59(2 \mathrm{H}, \mathrm{m}) .{ }^{13} \mathrm{C} \mathrm{NMR}\left(\mathrm{CDCl}_{3}, 100 \mathrm{MHz}\right): \delta$ $=166.1,159.2,148.6,148.0,145.7,131.9,130.5,130.4,128.9,115.8,115.2,115.0,113.4,56.08$, $55.95,55.15,53.46,44.64,36.09,32.54,25.10,24.42$.

3,6,7-Trimethoxy-11,12,13,14,14a,15-hexahydro-9H-phenanthro[9,10-b]quinolizin-9-one (17). To a solution of compound $16(0.12 \mathrm{~g}, 0.24 \mathrm{mmol})$ in DMA $(5.3 \mathrm{~mL}), \mathrm{Pd}(\mathrm{OAc})_{2}(13 \mathrm{mg}, 0.058$ mmol), 2'-(diphenylphosphino)-N,N'-dimethyl-(1,1'-biphenyl)-2-amine (28 mg, $0.072 \mathrm{mmol})$ and $\mathrm{K}_{2} \mathrm{CO}_{3}(0.066 \mathrm{~g}, 0.48 \mathrm{mmol})$ were added and the new mixture was heated at $125^{\circ} \mathrm{C}$ for $5 \mathrm{~h}$. After the completion of the reaction, $\mathrm{H}_{2} \mathrm{O}$ was added and the aqueous layer was extracted 3 times with EtOAc. The combined organic layers were washed with water and brine, dried with $\mathrm{Na}_{2} \mathrm{SO}_{4}$, 
filtered and evaporated. The residue was purified by flash column chromatography (Hex/EtOAc 4:6) to provide compound $\mathbf{1 7}$ as oil. Yield $60 \% ; \mathrm{R}_{f}=0.46(\mathrm{Hex} / \mathrm{EtOAc}, 3: 7) ; \mathbf{1 7 a}:[a]_{D}^{20}=-108.4$ $\left(c=0.44\right.$ in $\left.\mathrm{CHCl}_{3}\right)$, HR-MS calculated for $\mathrm{C}_{24} \mathrm{H}_{26} \mathrm{NO}_{4} 392.1861$, found $392.1850 ; \mathbf{1 7 b}$ : $[a]_{D}^{1 \mathbf{9}}=+$ $110.2\left(c=0.65\right.$ in $\left.\mathrm{CHCl}_{3}\right)$, HR-MS found 392.1847. ${ }^{1} \mathrm{H} \mathrm{NMR}\left(\mathrm{CDCl}_{3}, 400 \mathrm{MHz}\right): \delta=9.41(1 \mathrm{H}, \mathrm{s})$, $8.01(1 \mathrm{H}, \mathrm{d}, J=8.8 \mathrm{~Hz}), 7.88(1 \mathrm{H}, \mathrm{d}, J=3.2 \mathrm{~Hz}), 7.87(1 \mathrm{H}, \mathrm{s}), 7.23(1 \mathrm{H}, \mathrm{dd}, J=9.2 \mathrm{~Hz} J=2.4 \mathrm{~Hz})$, $4.74(1 \mathrm{H}$, br. d, $J=11.6 \mathrm{~Hz}), 4.12(6 \mathrm{H}, \mathrm{s}), 4.05(3 \mathrm{H}, \mathrm{s}), 3.64-3.56(1 \mathrm{H}, \mathrm{m}), 3.52(1 \mathrm{H}, \mathrm{dd}, J=16.4$ $\mathrm{Hz} J=4.8 \mathrm{~Hz}), 3.05(1 \mathrm{H}, \mathrm{dd}, J=16.0 \mathrm{~Hz} J=5.2 \mathrm{~Hz}), 2.90(1 \mathrm{H}, \mathrm{td}, J=13.2 \mathrm{~Hz} J=3.2 \mathrm{~Hz}), 2.01$ $(1 \mathrm{H}$, br. d, $J=10.0 \mathrm{~Hz}), 1.93-1.91(2 \mathrm{H}, \mathrm{m}), 1.67-1.48(3 \mathrm{H}, \mathrm{m}) .{ }^{13} \mathrm{C} \mathrm{NMR}\left(\mathrm{CDCl}_{3}, 100 \mathrm{MHz}\right): \delta$ $=168.2,160.2,150.2,149.0,135.1,133.9,127.2,126.4,125.2,123.4,120.3,116.1,109.5,105.1$, 103.7, 56.63, 56.52, 56.19, 53.54, 43.48, 36.65, 33.37, 25.39, 23.64. EI-MS: 391 [M].

\section{3,6,7-Trimethoxy-11,12,13,14,14a,15-hexahydro-9H-dibenzo[f,h]pyrido[1,2- $b]$ isoquinoline,}

Rac-boehmeriasin A (1, path A). To a solution of 3,6,7-trimethoxy-12,13,14,14a-tetrahydro-9Hdibenzo[f,h]pyrido[1,2-b]isoquinolin-15(11H)-one (10) $(391 \mathrm{mg}, 1.0 \mathrm{mmol})$ in THF (5 mL, cooled to $\left.0{ }^{\circ} \mathrm{C}\right) \mathrm{LiAlH}_{4}(100 \mathrm{mg}, 2.6 \mathrm{mmol})$ was added portionwise. After $10 \mathrm{~min}$ the mixture was allowed to warm to $\mathrm{rt}$ where it was stirred for $2 \mathrm{~h}$, prior to careful quenching by addition of aqueous $\mathrm{NH}_{4} \mathrm{Cl}$ solution. After aqueous extraction with DCM the combined organic layers were dried over anhydrous $\mathrm{Na}_{2} \mathrm{SO}_{4}$ and evaporated under reduced pressure to give the intermediate aminoalcohol product as yellow oil which was not purified further. This crude material was redissolved in DCM $(2 \mathrm{~mL})$ and combined with TFA $(0.3 \mathrm{~mL})$ and $\mathrm{Et}_{3} \mathrm{SiH}(0.3 \mathrm{~mL})$. After stirring for $4 \mathrm{~h}$ at $40{ }^{\circ} \mathrm{C}$ the reaction had reached completion (monitored by LC-MS) and was quenched by addition of aqueous $\mathrm{NaHCO}_{3}$ solution. The crude product was isolated after aqueous extraction as yellow foam. Final purification was accomplished by flash column chromatography furnishing racemic boehmeriasin A (1) as solid (308 mg, 82\%) after evaporation of the solvents. IR (neat) $v 2931.1(\mathrm{~m}), 1610.4(\mathrm{~m})$, $1511.5(\mathrm{~s}), 1467.9(\mathrm{~s}), 1253.9(\mathrm{~s}), 1201.9(\mathrm{~s}), 1138.6(\mathrm{~s}), 1038.7(\mathrm{~s}), 837.8(\mathrm{~m}), 783.1(\mathrm{~m}), 728.9(\mathrm{~s})$ 
cm-1. LR-MS (ESI): $377.9(\mathrm{M}+\mathrm{H})$. HR-MS: calculated for $\mathrm{C}_{24} \mathrm{H}_{28} \mathrm{O}_{3} \mathrm{~N}$ 378.2069, found 378.2055 $(\Delta-3.7 \mathrm{ppm})$.

HPLC: (AD $5 \mathrm{~cm}$, EtOH: Hexane 9:1, $1 \mathrm{ml} / \mathrm{min}, 22{ }^{\circ} \mathrm{C}$ ) can be used in order to achieve resolution of racemic boehmeriasin A (see Supporting Information).

\section{3,6,7-Trimethoxy-11,12,13,14,14a,15-hexahydro-9H-dibenzo[f, $h]$ pyrido[1,2- $b]$ isoquinoline,}

boehmeriasin A $(1$, path $\boldsymbol{B})$. To a cooled at $0{ }^{\circ} \mathrm{C}$ suspension of $\mathrm{LiAlH}_{4}(0.020 \mathrm{~g}, 0.49 \mathrm{mmol})$ in THF (5 mL), a solution of compound 17 (48 mg, $0.12 \mathrm{mmol})$ in THF (2.5 mL) was added dropwise and the new mixture was refluxed for $2 \mathrm{~h}$. After the completion of the reaction, the reaction mixture was cooled at $0{ }^{\circ} \mathrm{C}$, and carefully quenched by addition of $10 \% \mathrm{NaOH}$ aqueous solution and after the THF was evaporated in vacuum. Then, the aqueous layer was extracted 3 times with EtOAc. The combined organic layers were washed with water and brine, dried with $\mathrm{Na}_{2} \mathrm{SO}_{4}$, filtered and evaporated. The residue was purified by flash column chromatography (DCM/MeOH 9.6:0.4) to provide boehmeriasin A (1) as solid. Yield 80\%; $\mathrm{R}_{f}=0.24(\mathrm{DCM} / \mathrm{MeOH}, 9.6: 0.4) ; \mathbf{1 a}:[a]_{D}^{2 \mathbf{2}}=-$ $79.2(c=0.12$ in $\mathrm{MeOH}), \mathrm{HR}-\mathrm{MS}$ : calculated for $\mathrm{C}_{24} \mathrm{H}_{28} \mathrm{O}_{3} \mathrm{~N}$ 378.2069, found 378.2057. Anal. Calcd for $\mathrm{C}_{24} \mathrm{H}_{27} \mathrm{NO}_{3}$ : C, 76.36; H, 7.21; N, 3.71. Found: C, 75.58; H, 7.02; N, 3.56; 1b: [a] $]_{D}^{2 \mathbf{z}}=+$ 80.6 ( $c=0.10$ in $\mathrm{MeOH}$ ), HR-MS: found 378.2058; Found: C, 75.53; H, 7.04; N, 3.53. ${ }^{1} \mathrm{H}$ NMR $\left(\mathrm{CDCl}_{3}, 400 \mathrm{MHz}\right): \delta=7.92-7.90(3 \mathrm{H}, \mathrm{m}), 7.22(1 \mathrm{H}, \mathrm{dd}, J=8.8 \mathrm{~Hz} J=2.4 \mathrm{~Hz}), 7.14(1 \mathrm{H}, \mathrm{s}), 4.64$ $(1 \mathrm{H}, \mathrm{d}, J=15.2 \mathrm{~Hz}), 4.12(3 \mathrm{H}, \mathrm{s}), 4.07(3 \mathrm{H}, \mathrm{s}), 4.03(3 \mathrm{H}, \mathrm{s}), 3.58(1 \mathrm{H}, \mathrm{d}, J=15.2 \mathrm{~Hz}), 3.30(1 \mathrm{H}, \mathrm{d}$, $J=11.2 \mathrm{~Hz}), 3.18(1 \mathrm{H}, \mathrm{dd}, J=16.4 \mathrm{~Hz} J=2.8 \mathrm{~Hz}), 2.94(1 \mathrm{H}, \mathrm{dd}, J=16.4 \mathrm{~Hz} J=6.0 \mathrm{~Hz}), 2.41-$ $2.29(2 \mathrm{H}, \mathrm{m}), 2.03(1 \mathrm{H}, \mathrm{d}, J=13.2 \mathrm{~Hz}), 1.92-1.78(3 \mathrm{H}, \mathrm{m}), 1.56-1.45(2 \mathrm{H}, \mathrm{m}) .{ }^{13} \mathrm{C} \mathrm{NMR}$ $\left(\mathrm{CDCl}_{3}, 100 \mathrm{MHz}\right): \delta=158.2,150.1,148.9,130.9,126.6,125.9,125.7,124.9,123.9,115.4,105.3$, $104.7,103.8,58.19,57.05,56.84,56.66,56.19,35.35,34.44,26.67,25.05$. 


\section{Virtual Screening}

$(R)$ - and $(S)$-boehmeriasin A were used as input structures for Hurakan running the jobs on default parameters.

\section{Biological Evaluation.}

Cell proliferation: Endothelial cells. Bovine aortic endothelial cells (BAEC) and human dermal microvascular endothelial cells (HMEC-1) were seeded in 48-well plates at 10,000 cells/well and 20,000 cells/well, respectively. After 24 h, 5-fold dilutions of the compounds were added. The cells were allowed to proliferate 3 days (or 4 days for HMEC-1) in the presence of the compounds, trypsinized, and counted by means of a Coulter counter (Analis, Belgium). Tumor cells. Human cervical carcinoma (HeLa) cells were seeded in 96-well plates at 15,000 cells/well in the presence of different concentrations of the compounds. After 4 days of incubation, the cells were trypsinized and counted in a Coulter counter. Suspension cells (Mouse leukemia L1210 and human lymphoid Cem cells) were seeded in 96-well plates at 60,000 cells/well in the presence of different concentrations of the compounds. L1210 and Cem cells were allowed to proliferate for $48 \mathrm{~h}$ or $96 \mathrm{~h}$, respectively and then counted in a Coulter counter. The $50 \%$ inhibitory concentration $\left(\mathrm{IC}_{50}\right)$ was defined as the compound concentration required to reduce cell proliferation by $50 \%$. Combretastatin A-4 phosphate was added as reference compound.

Analysis of in vitro sirtuin inhibition. SIRT1 and SIRT2 in Vitro Assay. The compounds were studied using the Fluor de Lys fluorescence assays which are described in the BioMol product sheet (Enzo Life Sciences). In assays the BioMol KI177 substrate was used for SIRT1 and the KI179 substrate for SIRT2. The determined Km value of SIRT1 for KI177 was $58 \mu \mathrm{M}$ and the Km of SIRT2 for KI179 was $198 \mu \mathrm{M}^{32}$ The Km values of SIRT1 and SIRT2 were $558 \mu \mathrm{M}$ and $547 \mu \mathrm{M}$ for $\mathrm{NAD}+$ reported by BioMol, respectively. 
Briefly, assays were carried out using the Fluor de Lys acetylated peptide substrate at $0.7 \mathrm{Km}$ and NAD+ (Sigma N6522 or BioMol KI282) at $0.9 \mathrm{Km}$, recombinant GST-SIRT1/2-enzyme and SIRT assay buffer (KI286). GST-SIRT1 and GST-SIRT2 were produced as described previously. ${ }^{33,34}$ The buffer together with Fluor de Lys acetylated peptide substrate, NAD+ and DMSO/compounds in DMSO $(2.5 \mu \mathrm{L}$ in $50 \mu \mathrm{L}$ total reaction volume; DMSO from Sigma, D2650) were preincubated for $5 \mathrm{~min}$ at room temperature. Then enzyme was added to start the reaction. The reaction mixture was incubated for one hour at $37{ }^{\circ} \mathrm{C}$ and after that, Fluor de Lys developer (KI176) and $2 \mathrm{mM}$ nicotinamide (KI283) in SIRT assay buffer (total volume $50 \mu \mathrm{L}$ ) were added. The incubation was continued for $45 \mathrm{~min}$ at $37^{\circ} \mathrm{C}$. Finally, fluorescence readings were obtained using EnVision 2104 Multilabel Reader (PerkinElmer) with excitation wavelength $370 \mathrm{~nm}$ and emission $460 \mathrm{~nm}$.

Topoisomerase-Mediated DNA Relaxation. Supercoiled pBR322 plasmid DNA (0.25 $\mu \mathrm{g}$, Fermentas Life Sciences) was incubated with 1U topoisomerase II (human recombinant topoisomerase II $\alpha$, USB Corporation) or $2 \mathrm{U}$ topoisomerase I (human recombinant topoisomerase I, TopoGen) and the test compounds as indicated, for $60 \mathrm{~min}$ at $37^{\circ} \mathrm{C}$ in $20 \mu \mathrm{L}$ reaction buffer.

Reactions were stopped by adding $4 \mu \mathrm{L}$ stop buffer (5\% sodium dodecyl sulfate (SDS), $0.125 \%$ bromophenol blue, and $25 \%$ glycerol), $50 \mu \mathrm{g} / \mathrm{mL}$ proteinase $\mathrm{K}$ (Sigma) and incubating for a further $30 \mathrm{~min}$ at $37{ }^{\circ} \mathrm{C}$. The samples were separated by electrophoresis on a $1 \%$ agarose gel at room temperature. The gels were stained with ethidium bromide $1 \mu \mathrm{g} / \mathrm{mL}$ in TAE buffer $(0.04 \mathrm{M}$ Trisacetate and 0.001 M EDTA), transilluminated by UV light, and fluorescence emission was visualized by a CCD camera coupled to a Bio-Rad Gel Doc XR apparatus.

Topoisomerase II-mediated DNA cleavage. Reaction mixtures $(20 \mu \mathrm{L})$ containing $10 \mathrm{mM}$ Tris$\mathrm{HCl}(\mathrm{pH}=7.9), 50 \mathrm{mM} \mathrm{NaCl}, 50 \mathrm{mM} \mathrm{KCl}, 5 \mathrm{mM} \mathrm{MgCl} 2,0.1 \mathrm{mM}$ EDTA, $15 \mu \mathrm{g} / \mathrm{mL}$ bovine serum albumin, $1 \mathrm{mM}$ ATP, $0.25 \mu \mathrm{g}$ pBR322 plasmid DNA (Fermentas Life Sciences), $10 \mathrm{U}$ topoisomerase II (human recombinant topoisomerase II $\alpha$, USB Corporation) and test compounds 
were incubated for $60 \mathrm{~min}$ at $37^{\circ} \mathrm{C}$. Reactions were stopped by adding $4 \mu \mathrm{L}$ stop buffer $(5 \%$ SDS, $0.125 \%$ bromophenol blue and $25 \%$ glycerol), $50 \mu \mathrm{g} / \mathrm{mL}$ proteinase $\mathrm{K}$ (Sigma) and incubating for a further $30 \mathrm{~min}$ at $37{ }^{\circ} \mathrm{C}$. The samples were separated by electrophoresis on a $1 \%$ agarose gel containing ethidium bromide $0.5 \mu \mathrm{g} / \mathrm{mL}$ at room temperature in TBE buffer $(0.09 \mathrm{M}$ Tris-borate and 0.002 M EDTA), transilluminated by UV light, and fluorescence emission was visualized by a CCD camera coupled to a Bio-Rad Gel Doc XR apparatus.

Topoisomerase I-mediated DNA cleavage. Reaction mixtures $(20 \mu \mathrm{L})$ containing $35 \mathrm{mM}$ Tris$\mathrm{HCl}(\mathrm{pH}=8.0), 72 \mathrm{mM} \mathrm{KCl}, 5 \mathrm{mM} \mathrm{MgCl} 2,5 \mathrm{mM}$ DTT, $5 \mathrm{mM}$ spermidine, $0.01 \%$ bovine serum albumin , 20 ng pBR322 plasmid DNA (Fermentas Life Sciences), 5 U topoisomerase I (human recombinant topoisomerase I, TopoGen) and test compounds were incubated for $60 \mathrm{~min}$ at $37^{\circ} \mathrm{C}$. Reactions were stopped by adding $4 \mu \mathrm{L}$ of stop buffer (5\% SDS, $0.125 \%$ bromophenol blue and $25 \%$ glycerol), $50 \mu \mathrm{g} / \mathrm{mL}$ proteinase $\mathrm{K}$ (Sigma) and incubating for a further $30 \mathrm{~min}$ at $37^{\circ} \mathrm{C}$. The samples were separated by electrophoresis on a $1 \%$ agarose gel containing ethidium bromide 0.5 $\mu \mathrm{g} / \mathrm{mL}$ (Sigma) at room temperature in TBE buffer (0.09 M Tris-borate and 0.002 M EDTA), transilluminated by UV light, and fluorescence emission was visualized by a CCD camera coupled to a Bio-Rad Gel Doc XR apparatus.

\section{Docking Studies.}

Topoisomerase: $(R)$ - and $(S)$-Boehmeriasin A were docked in the enzyme mediated DNA cleavage site in the crystal structure of the topoisomerase I and of the topoisomerase II-beta, both in complex with DNA (PDB id 1T8I and 4G0U respectively) ${ }^{35,36}$ using AutoDock 4.2 software. ${ }^{37}$ All crystallographic water molecules were removed as well as the cocrystallized ligands. A 60x60x60 grid of points in the $\mathrm{x}, \mathrm{y}$ and $\mathrm{z}$ direction respectively was built centered on the center of mass of the removed ligand; a grid spacing of $0.375 \AA$ was used. A Lamarkian genetic algorithm ${ }^{38}$ was employed for the docking simulation, performing 100 independent runs per molecule. In each run, 
a population of 50 individuals evolved along 27000 generations and a maximum number of 25 million energy evaluations were performed. The best fit (lowest docked energy) solutions of the 100 independent runs for were stored for subsequent analysis. Cluster analysis was performed on the results using an RMSD tolerance of $2.0 \AA$.

Sirtuins: (R)- and (S)-Boehmeriasin A were docked in the crysral structure of SIRT1 complex with Ex-527(PDB id 4I5I) ${ }^{39}$ and the homology model of SIRT2 ${ }^{40}$ using Schrödinger's Glide software. ${ }^{41}$ The protein structure was preprocessed with Protein Preparation Wizard of Schrödinger Maestro using standard settings (add hydrogens, assign bond orders, create zero order bonds to metals and disulfide bonds and delete waters beyond $5 \AA$ from heteroatoms), the hydrogen bonds were assigned and the prepared structure was minimized using OPLS_2005 force field and restrained minimization (heavy atom converging RMSD $0.30 \AA$ ). The Glide grid was constructed for ligands < $20 \AA$ in length and the center of the grid was defined into the place of the nicotinamide-moiety (so called C-pocket) for SIRT1 based on co-crystallized ligand, EX-527. For SIRT2 the center of the grid was defined based on the residues Ile93, Ile169 and Phe119 (residue numbering in SIRT2). Several docking runs were performed and the best scored results were visually inspected.

\section{ACKNOWLEDGEMENTS}

This research has been developed under the umbrella of CM1106 COST Action "Chemical Approaches for Targeting Drug Resistance in Cancer Stem Cells”. D. Passarella and G. Broggini thank PRIN 2012 "Identification, sustainable synthesis and study of molecular drugs efficacy in brain tumors treatment.". The authors express their gratitude to Ms. Ioana Stupariu for the revision of the manuscript. 


\section{References:}

1. Luo, Y.; Liu, Y.; Luo, D.; Gao, X.; Li, B.; Zhang, G. Cytotoxic Alkaloids from Boehmeria siamensis. Planta Medica 2003, 69, 842-845.

2. Wei, H.; Yan, J.; Liu, J.; Luo, D.; Zhang, J.; Gao, X. Genes Involved in the Anti-Cancer Effect of a Potent New Compound Boehmeriasin A on Breast Cancer Cell. J. Med. Plants Res. 2009, 3, $35-44$.

3. Yan, J.; Luo, D.; Luo, Y.; Gao, X.; Zhang, G. Induction of G1 Arrest and Differentiation in MDA-MB-231 Breast Cancer Cell by Boehmeriasin A, a Novel Compound from Plant. Int. J. Gynecol. Cancer 2006, 16, 165-170.

4. Cui, M.; Wang, Q. Total Synthesis of Phenanthro-Quinolizidine Alkaloids: ( \pm )-Cryptopleurine, $( \pm)$-Boehmeriasin A, ( \pm )-Boehmeriasin B and ( \pm )-Hydroxycryptopleurine. Eur. J. Org. Chem. 2009, 5445-5451. a) S. Yamashita, N. Kurono,

5. H. Senboku, M. Tokuda, K. Orito, Eur. J. Org. Chem. 2009, 1173-1180;

6. S. Kim, Y. M. Lee, J. Lee, T. Lee, Y. Fu, Y. Song, J. Cho, D. Kim, J. Org. Chem. 2007, 72, 4886-4891;

7. A. Fürstner, J. W. J. Kennedy, Chem. Eur. J. 2006, 12, 7398-7410;

8. S. Kim, T. Lee, E. Lee, J. Lee, G.-j. Fan, S. K. Lee, D. Kim, J. Org. Chem. 2004, 69, 3144-3149;

9. S. Lebrun, A. Couture, E. Deniau, P. Grandclaudon, Tetrahedron 1999, 55, 2659-2670;

10. H. Suzuki, S. Aoyagi, C. Kibayashi, J. Org. Chem. 1995, 60, 6114-6122;

11. H. Suzuki, S. Aoyagi, C. Kibayashi, Tetrahedron Lett. 1995, 36, 935-936.

12. Wang, Z.; Wang, Q. Highly Efficient Synthesis of Phenanthroquinolizidine Alkaloids via Parham-Type Cycliacylation. Tetrahedron Lett. 2010, 51, 1377-1379.

13. Dumoulin, D.; Lebrun, S.; Couture, A.; Deniau, E.; Grandclaudon, P. First Asymmetric Synthesis of Boehmeriasin A. Eur. J. Org. Chem. 2010, 1943-1950.

14. Leighty, M. W.; Georg, G. I. Total Syntheses and Cytotoxicity of $(R)$ - and $(S)$-Boehmeriasin A. ACS Med. Chem. Lett. 2011, 2, 313-315.

15. Zeng, C.; Liu, H.; Zhang, M.; Guo, J.; Jiang, S.; Yu, S. Enantioselective Synthesis of Cryptopleurine and Boehmeriasin A via Organocatalytic Intramolecular Aza-Michael Addition. Synlett 2012, 23, 2251-2254.

16. Santamaría-Navarro, E; Nonell-Canals, A. Hurakan, ligand-based 3D screening software. Available at www.mindthebyte.com, 2013 
17. Angoli, M.; Barilli, A.; Lesma, G.; Passarella, D.; Riva, S.; Silvani, A.; Danieli, B. Remote Stereocenter Discrimination in the Enzymatic Resolution of Piperidine-2-ethanol. Short Enantioselective Synthesis of Sedamine and Allosedamine. J. Org. Chem. 2003, 68, 9525-9527.

18. Barilli, A.; Belinghieri, F.; Passarella, D.; Lesma, G.; Riva, S.; Silvani, A.; Danieli, B. Enzyme assisted enantioselective synthesis of the alkaloid (+)-aloperine. Tetrahedron: Asymmetry 2004, 15, 2921-2925.

19. Passarella, D.; Barilli, A.; Belinghieri, F.; Fassi, P.; Riva, S.; Sacchetti, A.; Silvani, A.; Danieli, B. Short enantioselective synthesis of sedridines, ethylnorlobelols and coniine via reagent-based differentiation. Tetrahedron: Asymmetry 2005, 16, 2225-2229.

20. Passarella, D.; Riva, S.; Grieco, G.; Cavallo, F.; Checa, B.; Arioli, F.; Riva, E.; Comi, D.; Danieli, B. Enantiopure N-Boc piperidine-2-ethanol for the synthesis of (+)- and (-)dumetorine, and (+)- and (-)-epidihydropinidine. Tetrahedron: Asymmetry 2009, 20, 192-197.

21. Riva, E.; Rencurosi, A.; Gagliardi, S.; Passarella, D.; Martinelli, M. Synthesis of (+)Dumetorine and Congeners by Using Flow Chemistry Technologies. Chem. Eur. J. 2011, 17, $6221-6226$.

22. Borsini, E.; Broggini, G.; Colombo, F.; Khansaa, M.; Fasana, A.; Galli, S.; Passarella, D.; Riva, E.; Riva, S. Enantiopure 2-piperidylacetaldehyde as a useful building block in the diversityoriented synthesis of polycyclic piperidine derivatives. Tetrahedron: Asymmetry 2011, 22, 264 269.

23. Stenlake, J. B.; Waigh, R. D.; Dewar, G. H.; Hughes, R.; Chapple, D. J.; Coker, G. G. Biodegradable neuromuscular blocking agents. Part 4. Atracurium Besylate and related polyalkylene di-esters. Eur. J. Med. Chem. - Chimica Therapeutica 1981-16, 6, 515-524.

24. Bento, A. P.; Gaulton, A.; Hersey, A.; Bellis, L. J.; Chambers, J.; Davies, M.; Kruger, F. A.; Light, Y.; Mak, L.; McGlinchey, S.; Nowotka, M.; Papadatos, G.; Santos, R.; Overington, J. P. The ChEMBL bioactivity database: an update. Nucleic Acids Research 2014, 42, D1083-D1090.

25. Christodoulou, M. S.; Sacchetti, A.; Ronchetti, V.; Caufin, S.; Silvani, A.; Lesma, G.; Fontana, G.; Minicone, F.; Riva, B.; Ventura, M.; Lahtela-Kakkonen, M.; Jarho, E.; Zuco, V.; Zunino, F.; Martinet, N.; Dapiaggi, F.; Pieraccini, S.; Sironi, M.; Dalla Via, L.; Gia, O. M.; Passarella, D. Quinazolinecarboline Alkaloid Evodiamine as Scaffold for Targeting Topoisomerase I and Sirtuins. Bioorg. Med. Chem. 2013, 21, 6920-6928.

26. Christodoulou, M. S.; Fokialakis, N.; Passarella, D.; García-Argáez, A. N.; Gia, O. M.; Pongratz, I.; Dalla Via, L.; Haroutounian, S. A. Synthesis and biological evaluation of novel tamoxifen analogues. Bioorg. Med. Chem. 2013, 21, 4120-4131. 
27. Christodoulou, M. S.; Zunino, F.; Zuco, V.; Borrelli, S.; Comi, D.; Fontana, G.; Martinelli, M.; Lorens, J.; Evensen, L.; Sironi, M.; Pieraccini, S.; Dalla Via, L.; Gia, O. M.; Passarella, D. Camptothecin-7-yl-methanthiole: Semisynthesis and Biological Evaluation. ChemMedChem 2012, 7, 1-11.

28. Riva, E.; Comi, D.; Borrelli, S.; Colombo, F.; Danieli, B.; Borlak, J.; Evensen, L.; Lorens, J. B.; Fontana, G.; Gia, O. M.; Dalla Via, L.; Passarella, D. Synthesis and biological evaluation of new camptothecin derivatives obtained by modification of position 20. Bioorg. Med. Chem. 2010, 18, 8660-8668.

29. Passarella, D.; Belinghieri, F.; Scarpellini, M.; Pratesi, G.; Zunino, F.; Gia, O. M.; Dalla Via, L.; Santoro, G.; Danieli, B. Synthesis and biological evaluation of pyrroloiminoquinone derivatives. Bioorg. Med. Chem. 2008, 16, 2431-2438.

30. Rotili, D.; Tarantino, D.; Carafa, V.; Lara, E.; Meade, S.; Botta, G.; Nebbioso, A.; Schemies, J.; Jung, M.; Kazantsev, A. G.; Esteller, M.; Fraga, M. F.; Altucci, L.; Mai, A. Identification of Triand Tetracyclic Pyrimidinediones as Sirtuin Inhibitors. ChemMedChem 2010, 5, 674-677.

31. Cosconati, S.; Forli, S.; Perryman, A. L.; Harris, R.; Goodsell, D. S.; Olson, A. J. Virtual screening with AutoDock: theory and practice. Expert Opin. Drug Discov. 2010, 5, 597-607.

32. Kiviranta, P.H.; Suuronen, T.; Wallen, E.A.A.; Leppanen, J.; Tervonen, J.; Kyrylenko, S.; Salminen, A.; Poso A.; Jarho, E.M. N $\varepsilon$-Thioacetyl-Lysine-Containing Tri-, Tetra-, and Pentapeptides as SIRT1 and SIRT2 Inhibitors J. Med. Chem. 2009, 52, 2153 - 2156

33. Kiviranta, P. H.; Leppänen, J.; Rinne, V. M.; Suuronen, T.; Kyrylenko, O.; Kyrylenko, S.; Kuusisto, E.; Tervo, A. J.; Järvinen, T.; Salminen, A.; Poso, A.; Wallén, E. A. A. N-(3-(4Hydroxyphenyl)-propenoyl)-amino acid tryptamides as SIRT2 inhibitors Bioorg. Med. Chem. Lett. 2007, 17, 2448 - 2451

34. Tervo, A. J.; Kyrylenko, S.; Niskanen, P.; Salminen, A.; Leppänen, J.; Nyronen, T. H.; Järvinen, T.; Poso, A. An in silico approach to discovering novel inhibitors of human sirtuin type $2 J$. Med. Chem. 2004, 47, 6292 - 6298

35. Staker, B. L.; M. D.Feese, M. D.; Cushman, M.; Pommier, Y.; Zembower, D.; Stewart, L.; Burgin, A.B. Structures of three classes of anticancer agents bound to the human topoisomerase I-DNA covalent complex J. Med. Chem. 2005, 48, 2336 - 2345

36. Chyuan-Chuan Wu, Yi-Ching Li, Ying-Ren Wang, Tsai-Kun Li and Nei-Li Chan, On the structural basis and design guidelines for type II topoisomerase-targeting anticancer drugs Nucleic Acid Research, 2013, 41, 10630 - 10640 
37. Morris, G.M.; Huey, R.; Lindstrom, W.; Sanner, M.F.; Belew, R.K.; Goodsell, D.S.; Olson, A.J.; Software news and updates AutoDock4 and AutoDockTools4: Automated docking with selective receptor flexibility J. Comput. Chem. 2009, 30, $2785-2791$.

38. Morris, G.M.; Goodsell,D.S.; Halliday, R.S.; Huey,R.; Hart, W.E.; Belew, R.K.; Olson, A.J.; Automated docking using a Lamarckian genetic algorithm and an empirical binding free energy function J. Comput. Chem. 1998, 19, $1639-1662$.

39. Zhao, X.; Allison, D.; Condon,; Zhang, F.; Gheyi, T.; Zhang, A.; Ashok, S.; Russell, M.; MacEwan, I.; Qian, Y.; Jamison, J.A.; Luz, J.G.; The $2.5 \AA$ crystal structure of the SIRT1 catalytic domain bound to nicotinamide adenine dinucleotide (NAD+) and an indole (EX527 analogue) reveals a novel mechanism of histone deacetylase inhibition J.Med.Chem. 2013, 56, $963-969$.

40. Mellini P,; Kokkola T,; Suuronen T,; Salo HS; Tolvanen L,; Mai A,; Lahtela-Kakkonen M,; Jarho EM.; Screen of pseudopeptidic inhibitors of human sirtuins 1-3: Two lead compounds with antiproliferative effects in cancer cells $\quad J$. Med. Chem. 2013, 56, 6681-6695.

41. Schrödinger Maestro, Glide, version 9.6, Schrödinger, LLC, New York, NY, 2013. 